\title{
Distribution of deep-water scleractinian and stylasterid corals across abiotic environmental gradients on three seamounts in the Anegada Passage
} \author{
Erik E Cordes \\ ${ }^{1}$ Department of Biology, Temple University, Philadelphia, PA, USA \\ 2 National Museum of Natural History, Smithsonian Institution, Washington, D.C., United States \\ 3 Wetland and Aquatric Research Center, US Geological Survey, Gainesville, Florida, USA \\ Corresponding Author: Steven R Auscavitch \\ Email address: steven.auscavitch@temple.edu
}

Steven R Auscavitch ${ }^{\text {Corresp., } 1}$, Jay J Lunden ${ }^{1}$, Alexandria Barkman ${ }^{1}$, Andrea M Quattrini ${ }^{2}$, Amanda W J Demopoulos ${ }^{3}$,

In the Caribbean Basin, the distribution and diversity patterns of deep-sea scleractinian corals and stylasterid hydrocorals are poorly known compared to their shallow water relatives. In this study, we examined species distribution and community assembly patterns of scleractinian and stylasterid corals on three high-profile seamounts within the Anegada Passage, a deep-water throughway linking the Caribbean Sea and western North Atlantic. Using remotely operated vehicle surveys conducted on the E/N Nautilus by the ROV Hercules in 2014, we characterized coral assemblages and seawater environmental variables between 162-2157 m on Dog Seamount, Conrad Seamount, and Noroît Seamount. In all, 13 morphospecies of scleractinian and stylasterid corals were identified from video with stylasterids being numerically more abundant than both colonial and solitary scleractinians. Cosmopolitan framework-forming species including Madrepora oculata and Solenosmilia variabilis were present but occurred in patchy distributions among the three seamounts. Framework-forming species occurred at or above the depth of the aragonite saturation horizon with stylasterid hydrocorals being the only coral taxon observed below $\Omega_{\text {arag }}$ values of 1 . Coral assemblage variation was found to be strongly associated with depth and aragonite saturation state, while other environmental variables exerted less influence. This study enhances our understanding of the factors that regulate scleractinian and stylasterid coral distribution in an underreported marginal sea and establishes a baseline for monitoring future environmental changes due to ocean acidification and deoxygenation in the tropical western Atlantic. 


\section{Distribution of deep-water scleractinian and}

2 stylasterid corals across abiotic environmental

3 gradients on three seamounts in the Anegada

4

5

6

\section{Passage}

Steven R. Auscavitch ${ }^{1}$, Jay J. Lunden ${ }^{1}$, Alexandria Barkman ${ }^{1}$, Andrea M. Quattrini ${ }^{2}$, Amanda W. J. Demopoulos ${ }^{3}$, Erik E. Cordes ${ }^{1}$

${ }^{1}$ Department of Biology, Temple University, Philadelphia, PA, USA.

${ }^{2}$ National Museum of Natural History, Smithsonian Institution, Washington, DC. USA.

${ }^{3}$ Wetland and Aquatic Research Center, U.S. Geological Survey, Gainesville, FL, USA.

\section{Corresponding Author:}

Steven R. Auscavitch ${ }^{1}$

steven.auscavitch@temple.edu

1900 N $12^{\text {th }}$ St. Philadelphia, PA, 19122, USA.

\section{Abstract}

corals and stylasterid hydrocorals are poorly known compared to their shallow water relatives. In this study, we examined species distribution and community assembly patterns of scleractinian and stylasterid corals on three high-profile seamounts within the Anegada Passage, a deep-water throughway linking the Caribbean Sea and western North Atlantic. Using remotely operated vehicle surveys conducted on the E/V Nautilus by the ROV Hercules in 2014, we characterized coral assemblages and seawater environmental variables between 162-2157 m on Dog Seamount, Conrad Seamount, and Noroît Seamount. In all, 13 morphospecies of scleractinian and stylasterid corals were identified from video with stylasterids being numerically more abundant than both colonial and solitary scleractinians. Cosmopolitan framework-forming species including Madrepora oculata and Solenosmilia variabilis were present but occurred in patchy 
32 distributions among the three seamounts. Framework-forming species occurred at or above the

33 depth of the aragonite saturation horizon with stylasterid hydrocorals being the only coral taxon

34 observed below $\Omega_{\text {arag }}$ values of 1 . Coral assemblage variation was found to be strongly associated

35 with depth and aragonite saturation state, while other environmental variables exerted less

36 influence. This study enhances our understanding of the factors that regulate scleractinian and

37 stylasterid coral distribution in an underreported marginal sea and establishes a baseline for

38 monitoring future environmental changes due to ocean acidification and deoxygenation in the

39 tropical western Atlantic.

40

\section{Introduction}

Global and regional modelling efforts in parallel with observational studies have

contributed to our understanding of the distribution of framework-forming azooxanthellate corals

in the deep sea (>200 m depth). However, a significant number of data deficient localities persist,

most often hindered by a lack of records from direct seafloor observation and in situ

environmental data. A number of environmental variables have been observed to control the

47 distribution of deep-water azooxanthellate scleractinian corals and stylasterid hydrocorals,

including parameters linked to depth, terrain, hydrography, and seawater chemistry (Guinotte et deep-water scleractinian diversity (Cairns, 2007), additional direct observational data are needed to validate modelling efforts.

$54\left(\Omega_{\text {arag }}\right)$ being greater than 1 , or supersaturated. However, some deep-water scleractinian corals, 
55 including the cosmopolitan species Solenosmilia variabilis and Enallopsammia rostrata, have

56 been reported well below the saturation horizon (the depth at which $\Omega_{\text {arag }}=1$ ) on the Tasmanian

57 Seamounts (Thresher et al., 2011). A more recent survey of seamounts in the Northwestern

58 Hawaiian Islands and Emperor Seamounts documented living colonial scleractinian reefs at $\Omega_{\text {arag }}$

59 as low as 0.71 (Baco et al., 2017). Previous studies lend support for targeted observational

60 surveys in underexplored regions in order to delineate species distribution patterns with respect

61 to aragonite saturation and other environmental variables. These efforts are particularly salient in

62 light of potential and ongoing anthropogenic impacts to deep-sea coral ecosystems (Ragnarsson

63 et al., 2017), including global climate change and ocean acidification (Gleckler et al., 2016;

64 Pérez et al., 2018), deep-water drilling and resource extraction (Cordes et al., 2016), bottom-

65 contact fishing (Watling \& Norse, 1998), and deep-sea crust mining (Miller et al., 2018).

66 The Greater-Lesser Antilles transition zone is one of the most sparsely surveyed yet

67 biogeographically important deep-water entries from the western Atlantic Ocean into the

68 Caribbean Basin. Topographic features, such as seamounts and other submarine banks associated

69 with deformation along tectonic plate boundaries, are important contributors to the

70 environmental complexity of the deep-sea benthos. In the Anegada Passage, Dog Seamount,

71 Conrad Seamount, Noroît Seamount, and Barracuda Bank are some of the most prominent of the

72 large ( $>2 \mathrm{~km}$ in height above the surrounding seafloor) seamounts and banks present, ranging

73 from abyssal to mesophotic depths. Typical environmental characteristics of seamounts,

74 including substrate heterogeneity, enhanced productivity and carbon flux, and variable currents

75 (Rogers, 2018), create the potential for deep-water biodiversity hotspots in the region and

76 elevated species abundance relative to the adjacent continental margins and slopes. Previous

77 studies indicate that at depths $>200 \mathrm{~m}$, azooxanthellate corals generally prefer hard substrata that 
78 exhibit topographic complexity (Roberts et al., 2009; Georgian, Shedd \& Cordes, 2014). As

79 such, seamounts are one example of topographically complex deep-water features that provide

80 ideal hard substrate for corals (Rogers, 1994). Yet very few seamount benthic communities in the

81 Caribbean region have been characterized with respect to these important abiotic gradients.

82 Throughout the tropical western Atlantic, scleractinian species diversity and distributions

83 are relatively well-known from shallow waters but the extent of their distribution below $150 \mathrm{~m}$ is

84 poorly understood. For deep-water azooxanthellate corals, 81 species have been reported at

85 depths greater than $50 \mathrm{~m}$ for the Greater and Lesser Antilles (Cairns, 2007). As with

86 scleractinians, stylasterid hydrocorals are reportedly diverse from the Lesser Antilles (Cairns,

87 1986), can occur in high densities in the tropical western Atlantic (Messing, Neumann \& Lang,

88 1990), and are composed of rigid, primarily aragonitic coralla (Cairns \& Macintyre, 1992).

89 Additionally, three-dimensional structures produced by deep-water stylasterids provide habitat

90 for fishes (Love, Lenarz \& Snook, 2010) and invertebrate fauna (Braga-Henriques et al., 2011;

91 Reed et al., 2013). Efforts have also been made to understand the biogeographic context of

92 Caribbean ecoregions using deep-water corals in order to support conservation strategies (Cairns

93 \& Chapman, 2001; Miloslavich et al., 2010; Hernández-Ávila, 2014). In the Caribbean Basin,

94 patterns in deep-sea coral beta diversity (e.g., species turnover) between ecoregions have been

95 attributed to topography and oceanography (Hernández-Ávila, 2014). Within the insular

96 Caribbean, the Greater Antilles and Lesser Antilles regions are found to diverge into two

97 ecoregions, one encompassing the Greater Antilles islands and the other the Lesser Antilles

98 islands, at continental slope depths (200-2000 m) (Hernández-Ávila, 2014). At larger

99 biogeographic scales and evolutionary time, deep-water currents or water masses have been

100 hypothesized as distribution pathways for constraining cosmopolitan habitat-forming corals like 
101 Lophelia pertusa in the western Atlantic (Arantes et al., 2009; Henry, 2011). While widespread

102 seamount surveys from the Caribbean Basin remain rare, the effect of environmental variables

103 like temperature, dissolved oxygen, and water mass has been demonstrated for demersal fishes

104 on seamounts in the Anegada Passage (Quattrini et al., 2017).

105 The present study focuses on describing patterns in the distribution of deep-water

106 scleractinians and stylasterid corals on three prominent seamounts in the northeastern Caribbean

107 Sea. In addition to the primary abiotic oceanographic variables including temperature, salinity,

108 and dissolved oxygen, we explore the distribution of aragonitic corals in the region with respect

109 to the aragonite saturation state in this region of the western Atlantic Ocean. As a suspected

110 driver of change in deep-water coral community structure, we also examine the relationship

111 between water mass structure and community similarity in the bathyal zone, hypothesizing that

112 different water masses would have distinct coral assemblages. Finally, we aim to identify abiotic

113 oceanographic variables that most strongly influence the presence of hard corals and their

114 contribution to changes in community similarity for this locality.

115

116

117

118

119

120

121

122

123

\section{Materials \& Methods}

\section{ROV Surveys}

This study examined sites within the Anegada Passage in the northeastern corner of the

Caribbean Sea (Fig. 1). Three seamounts of varying summit depths were surveyed in September 2014 using the ROV Hercules during E/V Nautilus cruise NA052 (Table 1). Three dives were conducted on Dog Seamount (276 to $1035 \mathrm{~m}$ depth), two were conducted on Conrad Seamount (162 to $1314 \mathrm{~m}$ depth), and two were conducted on Noroît Seamount (949 to $2206 \mathrm{~m}$ depth). 
124 Efforts were made to cover similar depth ranges on each feature for direct comparison as

125 permitted by the bathymetry.

126 The ROV was deployed to a maximum target depth on each seamount and generally

127 moved to shallower depths up slope. The ROV continuously traversed the seafloor as near to the

128 bottom as practical at a slow, steady speed ( $\sim 0.1-0.2 \mathrm{knots}, \sim 0.1 \mathrm{~m} / \mathrm{s})$; however, transects were

129 occasionally interrupted by stopping the ROV for sampling and detailed camera zooms. The

130 ROV was equipped with a high-definition camera and paired scaling lasers (10 cm apart). During

131 the dives, the forward-facing cameras were set on wide-angle view, but frequent snap-zooms (up

132 to $20 \mathrm{sec}$ ) were conducted to aid in species identification. The ROV was also equipped with a

133 Seabird FastCAT 49 conductivity-temperature-depth (CTD) logger and an Aanderaa oxygen

134 optode to measure dissolved oxygen (DO). The ROV was tracked on the seafloor using an ultra-

135 short baseline (USBL) tracking system as well as a Doppler Velocity Log (DVLNAV).

137 Seawater Collection and Carbonate Chemistry Analysis

138 Seawater samples $(n=34)$ were collected both in the water column and at the benthos

139 using Niskin bottles mounted to the ROV Hercules (Supplementary Table 1). On bottom,

140 seawater samples were collected within 1-2 meters of the benthos and usually co-occurred with

141 the observation of scleractinian colonies on the seafloor. For all seawater samples, co-located

142 physical data (pressure, temperature, salinity, and oxygen) were obtained using vehicle mounted

143 conductivity-temperature-depth (Paroscientific Digiquartz, SBE 49Plus) and oxygen (Aanderaa

144 Optode 3830) sensors, respectively. Upon recovery of the ROV, samples were immediately

145 transferred to $500 \mathrm{~mL}$ high-density polyethylene (HDPE) containers according to Best Practices

146 for Ocean $\mathrm{CO}_{2}$ measurements (Dickson, Sabine \& Christian, 2007). While HDPE containers are 
147 suitable for long-term storage of seawater for total alkalinity analyses (Huang, Wang \& Cai,

148 2012), they are not suitable for long-term storage for $\mathrm{pH}$ or dissolved inorganic carbon analyses

149 as they are permeable to $\mathrm{CO}_{2}$. Accordingly, $\mathrm{pH}$ was measured within 1 hour of collection

150 onboard the vessel. Immediately following $\mathrm{pH}$ measurement, samples were poisoned with 100

$151 \mu \mathrm{L}$ saturated mercuric chloride solution and stored in a cool, dark location. Total alkalinity was

152 measured in the laboratory in triplicate according to methods previously described (Lunden,

153 Georgian \& Cordes, 2013; Georgian et al., 2016a), and final $\Omega_{\text {arag }}$ values were computed using

154 CO2calc (Robbins et al., 2010). Due to the logistical challenge of pairing a discrete water sample

155 with each individual scleractinian coral observation, we generated a predictive model to

156 interpolate $\Omega_{\text {arag }}$ at the depth of each coral observation based on temperature, dissolved oxygen,

157 and salinity (for methodology see Georgian et al., 2016a).

158

159 ROV video analysis

160 Colonial and solitary coral occurrences were documented using high-definition video

161 transects during each of the ROV dives. Video segments where collections occurred, where the

162 vehicle was too high off the bottom, moving backwards, or of generally poor quality, were

163 removed from analysis. For the purpose of this analysis, we defined structure-forming corals as

164 colonial members of the Scleractinia and hydrozoan family Stylasteridae. Consistent

165 morphospecies identifications were used throughout the analyses. Voucher specimens for

166 morphological identification were obtained using the ROV platform. If necessary, further

167 identifications of coral species were made using taxonomic keys and assistance from taxonomic

168 specialists. Colony height was measured, where possible, by referencing scaling lasers.

169 Individuals or colonies above a 5-cm height threshold were typically identifiable based on laser 
170 scalers. If occurrences could not be readily identified below the 5-cm threshold, they were

171 omitted from analysis. Each observation was paired with an associated time-stamp for reference

172 to in situ environmental data (temperature, depth, dissolved oxygen concentration, and salinity)

173 collected by ROV CTD and oxygen optode sensors.

174

175

176

177

\section{Community Analyses}

Sampling effort was evaluated for seamounts individually and for all seamounts combined by 178 sample-based species accumulation curves. In order to assess community relationships among hard-coral assemblages, species abundance values (number of colonies or individuals for each species) were binned into $100 \mathrm{~m}$ depth segments for each seamount transect resulting in 28 total samples. Community-level analyses were conducted using standardized and $4^{\text {th }}$ root transformed species abundance data in PRIMER v7 with PERMANOVA add-on (Clarke \& Gorley, 2006; compiled into a Bray-Curtis resemblance matrix for further analyses. In order to test for significant differences among hard coral assemblages on different seamounts, a one-way analysis of similarity (ANOSIM) was conducted between features as well as between local water masses. Non-metric multidimensional scaling ordinations (nMDS) were conducted across all 28 samples. nMDS plots were overlaid with similarity profile (SIMPROF) analysis to show significant groupings of samples at the $95 \%$ level or greater (Clarke, Somerfield \& Gorley, 2008). Similarity percentage (SIMPER) tests were used to identify taxa that contributed disproportionately to assemblage similarities within and between seamounts and water masses. 
195 every transect. The mean was then $4^{\text {th }}$-root transformed and normalized within each variable. The 196 BEST (BIO-ENV) routine (Clarke, Somerfield \& Gorley, 2008) was applied to the dataset to 197 determine which environmental variables would be useful predictor variables. A distance-based 198 linear model (DistLM) with Akaike information criterion (AIC) was applied using the 199 PERMANOVA add-on in PRIMER v7 (Anderson, Gorley \& Clarke, 2008). Visualizations of the 200 resemblance matrix with predictor variables were observed using a dbRDA (distance-based 201 redundancy analysis) ordination with DistLM overlay.

202

203

204

205

206

207

208

209

210

211

212

213

214

215

216

217 218

\section{Results}

\section{Survey Summaries}

A total of 106 hours of bottom time was assessed across 7 dives (Table 1). Video records were annotated between the depth range of 162-2157 m. In all, 264 observations of solitary and framework-forming scleractinian corals and stylasterid hydrocorals were made across all three seamounts (Table 2). Three dives at Dog Seamount yielded 64 records from 284-849 m. From Conrad Seamount, 182 records were made from $166 \mathrm{~m}$ to $1230 \mathrm{~m}$ across 2 dives. The deepest two dives at Noroit Seamount had 18 records reported from 1014-1626 m. Stylasterids made up the majority (53\%) of coral observations, however most were observed at depths shallower than $400 \mathrm{~m}$ (Table 2). The majority of scleractinians observed were colonial, framework-forming species (100 colonies observed) while only 22 observations were made of solitary coral species, as they were often on or below the threshold for identification. For this reason, abundances of solitary scleractinians represent a minimum value. No scleractinians or stylasterids above the 5 $\mathrm{cm}$ size threshold were observed deeper than $1626 \mathrm{~m}$ on any seamount. 
219

220

221

222

223

224

225

226

227 228 229

230

231

232

233

234 235 236

237

238

239

240 241 Noroît Seamount.

242

243

Water Mass Structure

Downcast CTD profiles from the ROV sensors were plotted and assessed at each seamount using Ocean Data View v5 (Schlitzer, 2019). Profiles for each seamount were combined to create one consensus profile for the Anegada Passage (Fig. 2). Water masses were identified following published records of temperature, salinity, and dissolved oxygen profiles for the northeast Caribbean and Anegada Passage; these include Subtropical Underwater (SUW) 100-200 m, Sargasso Sea Water (SSW) 200-400 m, Tropical Atlantic Central Water (TACW) 400-700 m, Antarctic Intermediate Water (AAIW) 700-1200 m, and North Atlantic Deep Water (NADW) (>1200 m) (Morrison \& Nowlin, 1982).

\section{Carbonate chemistry analysis}

Water samples for carbonate chemistry analyses were collected at depth from $50 \mathrm{~m}$ to $2170 \mathrm{~m}$. Total alkalinity ranged from 2291.4 to $2405.9 \mu \mathrm{mol} \cdot \mathrm{kg}^{-1}$, and $\mathrm{pH}$ ranged from 7.83 to 8.11, with minimum $\mathrm{pH}$ observed at $795 \mathrm{~m}$ depth. Measured $\Omega_{\text {arag }}$ values from Niskin bottle collections ranged from 4.13 at $50 \mathrm{~m}$ depth to 0.99 at $2170 \mathrm{~m}$ depth. The aragonite saturation state of the water column was modelled according to the following equation: $\Omega_{\text {arag }}=(T \mathrm{x}$ $0.11407018)+(O \times 0.00302922)+(S \times 0.18168448)-6.5216044$ (stepwise backward regression, $\left.\mathrm{R}^{2}=0.9857, \mathrm{p}<0.001\right)$ where $T=$ temperature in ${ }^{\circ} \mathrm{C}, O=$ oxygen concentration in $\mu \mathrm{mol} \cdot \mathrm{L}^{-1}$, and $S=$ salinity in parts per thousand (ppt). From this, predicted $\Omega_{\text {arag }}$ values ranged from 4.11 to 1.05 , with highest value at $51 \mathrm{~m}$ at Dog Seamount and lowest value at $2195 \mathrm{~m}$ at 

colonies), but it was only observed on Conrad Seamount in a relatively narrow depth range, 409$569 \mathrm{~m}$. Many structure-forming colonies were found to be associated with boulder and low, outcropping, hard rock substrate. This was followed by the more widespread Madrepora oculata (22 colonies), which occurred between 784 and $1540 \mathrm{~m}$ on all seamounts (Fig. 3). Madrepora oculata, which displayed two different growth forms from thin and sparsely branching to thick, 250 robust colonies, possessed the widest depth distribution range for any colonial scleractinian coral. The deepest solitary scleractinian coral, Javania cailleti, was observed at $1626 \mathrm{~m}$; this occurrence corresponds with one of the lowest measured $\Omega_{\text {arag }}$ values of 1.01 . distributions than those at lower bathyal depths (>800 m) (Fig. 3). The sub-700 $\mathrm{m}$ assemblage was composed of three species of scleractinians (E. rostrata, M. oculata, and J. cailleti) and one stylasterid (Crypthelia $\mathrm{sp} .1$ ). The shallowest depths, usually coinciding with the seamount summit, were dominated by two species of stylasterids, Stylaster sp. 1 and Stylaster cf. duchassaingi, as well as one azooxanthellate scleractinian, Madracis myriaster. On Conrad Seamount, pink and purple coralline algal crusts were observed as deep as $256 \mathrm{~m}$ depth and continued to be observed through shallower depths dominated by sponges, stylasterids, and black corals. 
266 reference. The most abundant species, Stylaster sp. 1, was found in a narrow depth range

267 between 166-174 $\mathrm{m}$ on the summit of Conrad Seamount.

268

269 Patterns of Coral Occurrences with Aragonite Saturation State

$270 \quad$ Measured $\Omega_{\text {arag }}$ values from water collected adjacent to corals were not significantly

271 different (t-test, $N=9, t=-0.23341, p=0.818$ ) compared to what was calculated using the modelled 272 aragonite saturation state data (Supplementary Fig. 1). All paired water samplings adjacent to 273 coral observations occurred at or above the aragonite saturation horizon $\left(\Omega_{\mathrm{arag}}>1\right)$ (Table 3$)$.

274 Multiple water samples for a single species were collected for only M. oculata. A full table of all 27534 Niskin water bottle measurements and matched environmental variables is provided 276 (Supplementary Table 1).

277 Using predicted values derived from CTD and sensor data on temperature, oxygen 278 concentration, and salinity, all scleractinian and stylasterid corals were observed at $\Omega_{\text {arag }}$ values 279 of 0.99 to 3.45 (Fig. 4). For scleractinians, Javania cailleti occurred across the largest aragonite 280 saturation state range, between 1.01 and 1.77. Among the Stylasteridae, Crypthelia sp. 1 281 occurred across the greatest range of saturation states from as low as 0.99 up to 2.83 . Only three 282 species were observed at or around the aragonite saturation horizon based on predicted saturation 283 state values, Crypthelia sp. $1\left(\Omega_{\mathrm{arag}}=0.99\right)$, M. oculata $\left(\Omega_{\mathrm{arag}}=1.00\right)$ and J. cailleti $\left(\Omega_{\mathrm{arag}}=1.01\right)$. 284

\section{Community Structure Patterns}

286 Species-accumulation curves were evaluated for seamounts individually and in aggregate for 287 all seamounts. Combined, all seamounts (100-1700 m) revealed a more complete sampling effort 288 than among single seamount coral assemblages (Fig. 5). Individually, species accumulation 
289 curves for Dog, Conrad, and Noroît seamounts were not asymptotic, and therefore are likely to 290 accumulate additional coral species with increased sampling effort.

291 Analysis of similarity (two-way nested, depth within seamount, Global $R=0.122, p=0.05$ )

292 conducted among seamounts revealed significant differences in coral assemblages between Dog 293 and Noroît Seamounts $(R=0.544, p=0.006)$, but not Conrad and Dog seamounts $(R=-0.001$, $294 p=0.379)$ or Conrad and Noroît seamounts $(R=0.029, p=0.292)$ (Supplementary Table 2$)$. A one295 way ANOSIM (Global $R=0.464, p=0.001$ ) between water masses revealed significant differences 296 in coral assemblages between SSW and TACW $(R=0.46, p=0.003)$, AAIW $(R=0.53, p=0.002)$, 297 and NADW ( $R=0.60, p=0.008)$ as well as between TACW and NADW $(R=0.93, p=0.001)$ and 298 AAIW and NADW $(R=0.361, p=0.01)$ (Supplementary Table 3$)$.

299 Non-metric multi-dimensional ordination with SIMPROF groupings revealed five statistically 300 significant groupings; two shallow assemblages composed of $100 \mathrm{~m}$ depth-binned samples from 301 between 100-600 $\mathrm{m}$ and 200-400 $\mathrm{m}$, two mid-depth assemblages (500-700 $\mathrm{m}$ and 700-1100 m), 302 and one deep assemblage (1100-1600 m) (Fig. 6). Outliers from these groupings occurred in the 303 600-700 m and 1100-1200 m depth bins on Conrad Seamount and between 1300-1400 m on 304 Noroit Seamount. Within SIMPROF groupings, the shallowest depth grouping showed the 305 greatest amount of dissimilarity among samples (a metric of beta diversity) among the three 306 seamounts while the lowest occurred in the deepest group.

307 Dog Seamount exhibited the lowest beta diversity of coral assemblages among all three 308 seamounts and the highest average similarity at 61\% (one-way SIMPER analysis), with the 309 average similarity between $100 \mathrm{~m}$ depth bins being most strongly influenced by Crypthelia $\mathrm{sp}$.

3101 , which contributed to $96.6 \%$ of the relative abundance. Noroit Seamount had the second 311 highest similarity (38.2\%), with M. oculata accounting for $84.7 \%$ of the similarity. Conrad 
312 Seamount had the lowest average similarity (15\%), with stylasterids Crypthelia sp. 1 and

313 Stylaster cf. duchassaingi being the greatest contributors to average similarity with $48.4 \%$ and

$31421.5 \%$, respectively. Between seamounts, Noroît differed from Dog and Conrad, primarily due to

315 the higher abundance of M. oculata at Noroît Seamount. Noroît Seamount had nearly triple the

316 average abundance of $M$. oculata compared to Conrad Seamount. Conrad and Dog Seamounts

317 differed primarily due to the contribution of Crypthelia sp. 1 and M. myriaster, which were

318 present on Conrad at 2 to 3 times higher average abundance than at Dog Seamount.

319 Within water masses, the greatest average similarity of coral assemblages occurred within

320 NADW (54\%) followed by TACW (51\%) and finally SSW at (32\%). The abundance of

321 scleractinians was responsible for greater similarities within deep water masses (M. oculata and

322 Javania cailleti in NADW) while stylasterids were more commonly associated with driving

323 patterns of similarity within intermediate and shallower water masses (Crypthelia sp. 1 in

324 TACW, AAIW and Stylaster cf. duchassaingi in SSW). Between immediately adjacent water

325 masses, the greatest average dissimilarity was observed between SUW and SSW (92.3\%) and the

326 lowest between TACW and AAIW (56.7\%), indicating higher rates of turnover (beta diversity)

327 for shallower water masses than deeper ones.

328 Results from the BEST analysis indicated that the largest percentage of biological variation

329 was correlated with depth $(r=0.536)$. The BEST routine also indicated that the greatest

330 correlation occurred with the four combined factors of depth, $\Omega_{\text {arag, }}$, temperature, and dissolved

331 oxygen $(r=0.614)$. Sequential tests in the DistLM analysis indicated that depth (AIC=223.88,

$332 p=0.001)$ and $\Omega_{\text {arag }}(\mathrm{AIC}=215.87, p=0.001)$ were the greatest explanatory variables influencing

333 coral assemblages on seamounts in the Anegada Passage. Temperature, salinity, and oxygen did

334 not explain a significant portion of the biological variation in this test. Redundancy analyses 
335 resulted in $59.4 \%$ of the DistLM model variation explained by the primary axis (dbRDA1) and

$33632.6 \%$ explained by the second (dbRDA2) (Fig. 7). Likewise, the first axis explained $32.8 \%$ of

337 the total biological variation observed and the second axis explained $18 \%$. The primary axis was

338 most closely correlated with oxygen $(r=-0.82)$, while the second was most closely related to

339 temperature $(r=-0.61)$.

340

341

\section{Discussion}

Seamounts in the Anegada Passage were found to harbor communities of stony and lace

344

corals throughout the bathyal depth range from summit depths as shallow as $166 \mathrm{~m}$ to a

345

maximum of $1626 \mathrm{~m}$. Both stylasterid and scleractinian coral species with aragonitic skeletons

346

were largely present above the aragonite saturation horizon in this region of the western Atlantic

347 Ocean, with the understanding that sampling effort below the ASH was limited to one transect at

348 Noroit Seamount (Table 1). Nevertheless, we were able to identify the depth of the ASH as

349 occurring between 2000-2200 $\mathrm{m}$ in the Anegada Passage (Supplementary Fig. 1), which is

350 consistent with previous reports from the North Atlantic Ocean (Jiang et al., 2015). Only

351 stylasterids in the genus Crypthelia were observed to occur below the aragonite saturation

352 horizon $\left(\Omega_{\text {arag }}=0.99\right)$, but others, including the framework-forming species Madrepora oculata,

353 occurred at saturation states as low as $\Omega_{\text {arag }}=1.0$. Given the present findings and that aragonitic

354 coral species have been observed at depths below that of the ASH $(>2000 \mathrm{~m})$ in other parts of the

355 Caribbean Basin (Cairns 1979), it is still reasonable to expect that aragonitic corals can persist

356 below the aragonite saturation horizon within the Anegada Passage. Also noteworthy was the 
357 observation of live crustose coralline algae at a depth of $256 \mathrm{~m}$, which is comparable to the

358 deepest known record from San Salvador Island (268 m) in The Bahamas (Littler et al., 1986). between SSW (Sargasso Sea Water) and deeper water masses, but not the shallowest water mass, 361 Subtropical Underwater (SUW) and deeper strata of the water column. Oceanographic variables

362 that most strongly influenced the presence of aragonitic corals and their contribution to changes

363 in community similarity were depth and aragonite saturation state, with temperature, salinity, and

364 dissolved oxygen making less significant contributions.

365 The tropical western Atlantic is a known diversity center for azooxanthellate scleractinian 366 corals and stylasterid hydrocorals (Cairns, 2007, 2011). This study provides new distribution

367 records for deep-water coral species in the northeastern Caribbean and builds on existing efforts 368 to characterize the azooxanthellate coral fauna of the tropical western Atlantic (Cairns, 1979;

369 Cairns \& Chapman, 2001; Lutz \& Ginsburg, 2007). Specifically, 7 species or morphospecies of 370 stony corals within the genera Javania, Madrepora, Madracis, Enallopsammia, Dendrophyllia, 371 and Caryophyllia have been added to local species inventories in the Anegada Passage (Fig. 8).

372 New records from photographic and physical specimens aid in resolving the complex

373 biogeography of the Greater-Lesser Antilles Transition zone seamounts with respect to the

374 western North Atlantic (Supplementary Table 4). The paucity of records paired with

375 environmental parameters from global biogeographic databases makes these observations critical 376 to understanding the species distribution dynamics of marginal Atlantic seas and how coral

377 distribution may be affected by future ocean climatic changes.

378 Stony coral assemblages in the Anegada Passage were similar to those observed in other 379 parts of the western Atlantic Ocean with a few noteworthy absences. Absent from our records 
380 from the Anegada Passage seamounts include reef-forming species like L. pertusa and E.

381 profunda, as well as cosmopolitan cup coral species like Desmophyllum dianthus, which are

382 reportedly more common throughout the U.S. southeast continental shelf and Gulf of Mexico

383 (Schroeder et al., 2005; Reed, Weaver \& Pomponi, 2006; Brooke \& Schroeder, 2007; Lunden,

384 Georgian \& Cordes, 2013; Georgian et al., 2016a). While fossilized Lophelia rubble have been

385 reported in the Colombian Caribbean (Santodomingo et al., 2007) and live Lophelia has been

386 observed on the Brazilian continental margin (Arantes et al., 2009), the southern Caribbean

387 (Hernández-Ávila, 2014), and off Roatan, Honduras (Henry, 2011), members of this genus have

388 not been extensively reported in the insular Caribbean (OBIS, 2019).

389

We were also able to identify some variability in local distribution patterns among

390 seamounts for three colonial scleractinian species. Enallopsammia rostrata, Dendrophyllia

391 alternata, and Solenosmilia variabilis appear to have patchy distributions on the Anegada

392 Passage seamounts. For example, only two colonies of E. rostrata were observed, both on Dog

393 Seamount at $785 \mathrm{~m}$, and only five colonies of D. alternata were observed on Conrad Seamount

394 between 490-598 m (Fig. 3). Similarly, S. variabilis was only observed in patches on Conrad

395 Seamount from 490-569 m (Fig. 3). Solenosmilia has not been widely reported from the greater

396 Caribbean basin based on records from the Ocean Biogeographic Information System (OBIS,

397 2019), but is known to be a contributor to coral mound formation off Brazil (Raddatz et al.,

398 2020). Solenosmilia has been more commonly reported to asexually reproduce, and thus has a

399 relatively short dispersal ability (Miller \& Gunasekera, 2017), potentially explaining its patchy

400 distribution.

401 Several coral taxa encountered in the Anegada Passage are important species for

402 understanding biogeographic patterns of the Caribbean bathyal zone. Madracis myriaster was 
403 observed both on Dog and Conrad Seamounts, but only between $253-311 \mathrm{~m}$. This depth range

404 is also similar to that observed in the western North Atlantic off Bermuda (90-300 m)

405 (Stefanoudis et al. 2019). In the Caribbean, M. myriaster has been observed at similar depths and 406 in high densities during surveys by the ROV Deep Discoverer on the NOAA Ship Okeanos 407 Explorer east of Vieques Island and in the Mona Passage (Wagner et al., 2019). Northern and 408 eastern Caribbean coral communities at continental shelf depths have been found to be dissimilar 409 from the southern Caribbean, such that they may constitute distinct ecoregions (Hernández410 Ávila, 2014). These differences were found to be driven by differences in the abundance of $M$. 411 myriaster (Fig. 8C), which is more common at mesophotic and upper bathyal depths (Reyes et 412 al., 2005; Santodomingo et al., 2007; Hernández-Ávila, 2014; Stefanoudis et al. 2019). At lower 413 bathyal depths, regional biogeographic differences have also been attributed to variation in the 414 frequency of solitary scleractinian species (e.g. Stephanocyathus spp., Fungiacyathus sp.) that 415 may be difficult to detect during video transects (Hernández-Ávila, 2014). A greater diversity of 416 solitary scleractinian corals and smaller stylasterids may have been present in the video but could 417 not be documented due to limitations of ROV surveys (discussed in Everett \& Park, 2018). The 418 lack of easily identifiable diagnostic features from video, rugose terrain (e.g. overhangs and 419 ledges), and rarity make most smaller species difficult to identify from ROV surveys without 420 voucher specimens. A more thorough analysis incorporating modern (e.g. higher-resolution ROV 421 video surveys with in situ collections) and historical datasets (e.g. museum-archived specimens) 422 would be helpful in elucidating biogeographic patterns more broadly across the basin. Several species in the genus Crypthelia occur in the eastern Caribbean at bathyal depths 424 (Cairns, 1986). The difficulty of identifying stylasterids from ROV video remains a challenge in 425 establishing species occurrences, necessitating a voucher collection to confirm morphospecies 
426 identity. Nevertheless, the depth distribution, colony morphology, and coloration of Stylaster sp.

427 1, is consistent with Stylaster roseus (Pallas, 1766), a tropically-distributed western Atlantic

428 stylasterid from depths typically less than $500 \mathrm{~m}$ (OBIS, 2019). Crypthelia sp. and other

429 stylasterid species are more likely to be underreported due to their small size $(2-5 \mathrm{~cm})$, on the

430 threshold of being able to be accurately recorded from ROV video. These stylasterids were also

431 observed under overhangs which made obtaining an accurate account of their abundance

432 difficult. In this case, the reported occurrences of these corals represent a minimum value.

433 The ecological contribution of stylasterid corals is often understated, despite the ability of

434 some species to produce significant three-dimensional structures that can act as habitat for other

435 organisms. Larger structure-forming stylasterids are functionally analogous to some colonial

436 scleractinian corals in that they can provide habitat for larger organisms such as deep-water

437 fishes and invertebrates (Love, Lenarz \& Snook, 2010; Braga-Henriques et al., 2011). Crypthelia

438 spp., while relatively abundant in places and occurring over a wide range, were never observed

439 above $12 \mathrm{~cm}$ in overall height and were observed to be extremely brittle when attempting

440 collection (Fig. 9A). However, two species in the genus Stylaster, S. cf. duchassaingi (Fig. 9B)

441 and Stylaster sp. 1 (Fig. 9C), can be classified as potentially important three-dimensional

442 structure-forming species, primarily occurring between $150-400 \mathrm{~m}$ depth.

443 The carbonate mineralogy of most stylasterids is similar to scleractinians in that a

444 majority of known species, including those observed in this study, produce a skeleton composed

445 primarily of the mineral aragonite (Cairns, 2011), although some are calcitic in composition

446 (Cairns \& Macintyre, 1992). Stylasterids do share distribution characteristics and overlapping

447 depth ranges with many upper bathyal solitary and colonial scleractinian corals (Cairns, 1986, 
448 2011). Like scleractinians, stylasterid hydrocorals also exhibit a vulnerability to changing

449 aragonite saturation conditions over their depth distribution (Guinotte et al., 2006).

450

451

Knowledge of the chemical environment of deep-sea scleractinians has grown

452

significantly in recent years as empirical measurements of the carbonate system at deep-sea coral

453

habitats have been reported from different regions across the global ocean. On seamounts in the

454

Indian Ocean off the coast of SW Australia, the majority of framework-forming scleractinians -

455

including E. rostrata and $S$. variabilis - were found at $\Omega_{\text {arag }}$ values at or just below saturation,

456

suggesting a control on the lower limit of these species' distributions (Thresher et al., 2011).

457

However, live scleractinian reefs were recently discovered on seamounts in the North Pacific at

$458 \Omega_{\text {arag }}$ values as low as 0.71 (Baco et al., 2017) and as low as 0.81 off Southern California (Gómez

459 et al., 2018). Additionally, scleractinians have been observed below the ASH in the Indian Ocean

460 (Trotter et al., 2019) and South Atlantic Ocean (Barbosa, Davies \& Sumida, 2020). These

461 revelations indicate that, under the right conditions, scleractinian corals can persist in

462 undersaturated waters (Baco et al., 2017). Additionally, the presence of live tissue may buffer

463 against the effects of low $\mathrm{pH}$ (Venn et al., 2011), but the underlying dead coral framework may

464 be less resilient to undersaturated waters. Expanded surveys below $2000 \mathrm{~m}$ in northern

465 Caribbean, in tandem with additional effort in sampling of coral-adjacent deep-waters for

466 carbonate chemistry analysis will aid in better determining the controls on aragonitic coral

467 species distribution at lower bathyal depths in the tropical western Atlantic.

468 Productivity of the surface waters and export to the deep-sea benthos may contribute to

469 differences in species distribution and abundance of deep-sea corals. In a 2016 laboratory

470 experiment and field study comparing two spatially distinct and genetically isolated populations 
471 of the framework-forming scleractinian Lophelia pertusa, colonies from Norway exhibited

472 enhanced respiration and prey capture rates under acidified conditions compared to individuals

473 from the Gulf of Mexico (Georgian et al., 2016b). This study lends support to the hypothesis that

474 species are locally adapted to environmental conditions, including food supply, which may allow

475 individuals to better tolerate reduced carbonate saturation states.

\section{Conclusions}

477

478

Our results offer some insights to the distribution, diversity, and drivers of community

479 assembly of scleractinian and stylasterid deep-water corals in a data-deficient region of the tropical western Atlantic Ocean. These findings lend support for the efficacy of targeted exploration surveys to understand coral distribution with respect to environmental gradients in the deep-sea environment. The presence of aragonitic corals, largely occurring above the aragonite saturation horizon, was not unexpected, but more surprising was the presence of known framework-forming scleractinians, like Madrepora oculata, living at or just above $\Omega_{\text {arag }}$ $=1$ in this locality. Future work should seek to expand upon coral community inventories for this area to include members of the Octocorallia and Antipatharia, particularly to refine the relationship between community assembly and water mass structure. Increased taxonomic effort is needed to better identify cryptic coral morphospecies from the deep-sea benthos, and particularly for those size classes below the identification threshold for ROV video surveys. In the Atlantic Ocean, deep-water coral ecosystem health is likely to be negatively impacted by environmental change by the end of the current century. Warming deep-waters (Gleckler et al., 2016), thermohaline driven deep-water acidification (Pérez et al., 2018), and low latitude deoxygenation in the Atlantic (Montes et al., 2016) are among the greatest threats facing deep- 
495 variables reported here establish a critical baseline for the detection of the effects of deep ocean

496 change to seafloor communities, which is crucial to effective conservation.

497

498

499

500

501

502

503

504

505

506

507

508

509

510

511

512

513

514

515

516

517 Baco AR, Morgan N, Roark EB, Silva M, Shamberger KEF, Miller K. 2017. Defying

518 Dissolution: Discovery of Deep-Sea Scleractinian Coral Reefs in the North Pacific.

519 Scientific Reports 7:1-11. DOI: 10.1038/s41598-017-05492-w.

\section{Acknowledgements}

We would like to thank the efforts of the science party, master, and crew of the E/V Nautilus during the Exploration of the Anegada Passage (NA052) cruise. In addition, we would like to extend a special thanks to the Ocean Exploration Trust for their support. Taxonomic assistance in identifying voucher material was provided by Stephen Cairns (National Museum of Natural History, Smithsonian Institution) for scleractinian and stylasterid corals. We would also like to thank Jason Chaytor, Alex Rogers, Iván Hernández-Ávila, and Nadia Santodomingo for their feedback in the revision of this manuscript. Any use of trade, firm, or product names is for descriptive purposes only and does not imply endorsement by the U.S. Government.

\section{References}

Anderson M, Gorley RN, Clarke RK. 2008. Permanova + for Primer: Guide to Software and Statistical Methods. Primer-E Limited.

Arantes RCM, Castro CB, Pires DO, Seoane JCS. 2009. Depth and water mass zonation and species associations of cold-water octocoral and stony coral communities in the southwestern Atlantic. Marine Ecology Progress Series 397:71-79. DOI: $10.3354 /$ meps 08230 . 
520 Barbosa R V, Davies AJ, Sumida PYG. 2020. Habitat suitability and environmental niche 521 comparison of cold-water coral species along the Brazilian continental margin. Deep Sea 522 Research Part I: Oceanographic Research Papers 155:103147.

523 Braga-Henriques A, Carreiro-Silva M, Porteiro FM, De Matos V, Sampaio Í, Ocaña O, Ávila SP. 524 2011. The association between a deep-sea gastropod Pedicularia sicula (Caenogastropoda: 525 Pediculariidae) and its coral host Errina dabneyi (Hydrozoa: Stylasteridae) in the Azores. 526 ICES Journal of Marine Science 68:399-407. DOI: 10.1093/icesjms/fsq066.

527 Brooke S, Schroeder WW. 2007. State of deep coral ecosystems in the Gulf of Mexico region: 528 Texas to the Florida Straits. The State of Deep Coral Ecosystems of the United States:271529306.

530 Cairns SD. 1979. The deep-water Scleractinia of the Caribbean Sea and adjacent waters. Studies $531 \quad$ on the Fauna of Curaçao and other Caribbean Islands 57:1-341.

532 Cairns SD. 1986. A revision of the northwest Atlantic Stylasteridae (Coelenterata: Hydrozoa). 533 Smithsonian Contributions to Zoology 418:1-131. DOI: 10.5479/si.00810282.418.

534 Cairns SD. 2007. Deep-water corals: An overview with special reference to diversity and 535 distribution of deep-water scleractinian corals. Bulletin of Marine Science 81:311-322.

536 Cairns SD. 2011. Global Diversity of the Stylasteridae (Cnidaria: Hydrozoa: Athecatae). PLoS 537 ONE 6:1-13. DOI: 10.1371/journal.pone.0021670.

538 Cairns SD, Chapman RE. 2001. Biogeographic affinities of the North Atlantic deep-water 539 Scleractinia. Proceedings of the First International Symposium on Deep-Sea Corals 1:30$540 \quad 57$.

541 Cairns SD, Macintyre IG. 1992. Phylogenetic implications of calcium carbonate mineralogy in 542 the Stylasteridae (Cnidaria: Hydrozoa). Palaios 7:96-107. 
543 Clarke KR, Gorley RN. 2006. User manual/tutorial. PRIMER-E Ltd., Plymouth.

544 Clarke KR, Somerfield PJ, Gorley RN. 2008. Testing of null hypotheses in exploratory

545 community analyses: similarity profiles and biota-environment linkage. Journal of

546 Experimental Marine Biology and Ecology 366:56-69. DOI: 10.1016/j.jembe.2008.07.009.

547 Cordes EE, Jones DOB, Schlacher TA, Amon DJ, Bernardino AF, Brooke S, Carney R, DeLeo

548 DM, Dunlop KM, Escobar-Briones EG, Gates AR, Génio L, Gobin J, Henry LA, Herrera S,

549 Hoyt S, Joye M, Kark S, Mestre NC, Metaxas A, Pfeifer S, Sink K, Sweetman AK, Witte U.

550 2016. Environmental impacts of the deep-water oil and gas industry: A review to guide

551 management strategies. Frontiers in Environmental Science 4:1-26. DOI:

552

553

Davies AJ, Guinotte JM. 2011. Global habitat suitability for framework-forming cold-water

554 corals. PloS one 6:e18483.

Dickson AG, Sabine CL, Christian JR. 2007. Guide to best practices for ocean CO2

556 measurements. North Pacific Marine Science Organization.

557 https://www.oceanbestpractices.net/handle/11329/249

558 Everett M V., Park LK. 2018. Exploring deep-water coral communities using environmental 559 DNA. Deep Sea Research Part II: Topical Studies in Oceanography 150:229-241. DOI:

561 Georgian SE, DeLeo D, Durkin A, Gomez CE, Kurman M, Lunden JJ, Cordes EE. $2016 a$. 562 Oceanographic patterns and carbonate chemistry in the vicinity of cold-water coral reefs in 563 the Gulf of Mexico: Implications for resilience in a changing ocean. Limnology and $564 \quad$ Oceanography 61:648-665.

565 Georgian SE, Dupont S, Kurman M, Butler A, Strömberg SM, Larsson AI, Cordes EE. 2016 b. 
566 Biogeographic variability in the physiological response of the cold-water coral Lophelia 567 pertusa to ocean acidification. Marine Ecology 37:1345-1359. DOI: 10.1111/maec.12373.

568 Georgian SE, Shedd W, Cordes EE. 2014. High-resolution ecological niche modelling of the 569 cold-water coral Lophelia pertusa in the Gulf of Mexico. Marine Ecology Progress Series $570 \quad 506: 145-161$. DOI: $10.3354 /$ meps 10816.

571 Gleckler PJ, Durack PJ, Stouffer RJ, Johnson GC, Forest CE. 2016. Industrial-era global ocean 572 heat uptake doubles in recent decades. Nature Climate Change 6:394-398. DOI: $573 \quad 10.1038 /$ nclimate2915.

574 Gómez CE, Wickes L, Deegan D, Etnoyer PJ, Cordes EE. 2018. Growth and feeding of deep-sea 575 coral Lophelia pertusa from the California margin under simulated ocean acidification $576 \quad$ conditions. PeerJ 6:e5671. DOI: 10.7717/peerj.5671.

577 Guinotte JM, Orr J, Cairns S, Freiwald A, Morgan L, George R. 2006. Will human-induced 578 changes in seawater chemistry alter the distribution of deep-sea scleractinian corals? $579 \quad$ Frontiers in Ecology and the Environment 4:141-146.

580 Henry LA. 2011. A deep-sea coral 'gateway' in the northwestern Caribbean. In: Palomares 581 MLD, Pauly D (eds.), Too Precious to Drill: the Marine Biodiversity of Belize. Fisheries 582 Centre Research Reports 19:120-124. Fisheries Centre, University of British Columbia. 583 Hernández-Ávila I. 2014. Patterns of deep-water coral diversity in the Caribbean basin and 584 adjacent southern waters: An approach based on records from the R/V Pillsbury 585 expeditions. PLoS ONE 9:1-11. DOI: 10.1371/journal.pone.0092834.

586 Huang W, Wang Y, Cai W. 2012. Assessment of sample storage techniques for total alkalinity 587 and dissolved inorganic carbon in seawater. Limnology and oceanography: Methods $588 \quad 10: 711-717$. 
589 Jiang L, Feely RA, Carter BR, Greeley DJ, Gledhill DK, Arzayus KM. 2015. Climatological 590 distribution of aragonite saturation state in the global oceans. Global Biogeochemical $591 \quad$ Cycles 29:1656-1673. DOI: 10.1002/2015GB005198.

592 Littler MM, Littler DS, Blair SM, Norris JN. 1986. Deep-water plant communities from an 593 uncharted seamount off San Salvador Island, Bahamas: distribution, abundance, and primary 594 productivity. Deep-sea Research 33:881-892.

595 Love MS, Lenarz B, Snook L. 2010. A survey of the reef fishes, purple hydrocoral (Stylaster 596 californicus), and marine debris of Farnsworth Bank, Santa Catalina Island. Bulletin of $597 \quad$ Marine Science 86:35-52.

598 Lunden JJ, Georgian SE, Cordes EE. 2013. Aragonite saturation states at cold-water coral reefs 599 structured by Lophelia pertusa in the northern Gulf of Mexico. Limnology and $600 \quad$ Oceanography 58:354-362. DOI: 10.4319/1o.2013.58.1.0354.

601 Lutz SJ, Ginsburg RN. 2007. State of deep coral ecosystems in the Caribbean region: Puerto 602 Rico and the US Virgin Islands. The State of Deep Coral Ecosystems of the United States. 603 NOAA Technical Memorandum CRCP-3, Silver Spring, MD:307-365.

604 Messing CG, Neumann AC, Lang JC. 1990. Biozonation of Deep-Water Lithoherms and 605 Associated Hardgrounds in the Northeastern Straits of Florida. Palaios 5:15-33.

606 Miller KJ, Gunasekera RM. 2017. A comparison of genetic connectivity in two deep sea corals 607 to examine whether seamounts are isolated islands or stepping stones for dispersal. $608 \quad$ Scientific Reports 7:1-14. DOI: 10.1038/srep46103.

609 Miller KA, Thompson KF, Johnston P, Santillo D. 2018. An overview of seabed mining 610 including the current state of development, environmental impacts, and knowledge gaps. $611 \quad$ Frontiers in Marine Science 4:418. DOI: 10.3389/fmars.2017.00418. 
612 Miloslavich P, Díaz JM, Klein E, Alvarado JJ, Díaz C, Gobin J, Escobar-Briones E, Cruz-Motta

613 JJ, Weil E, Cortés J, Bastidas AC, Robertson R, Zapata F, Martín A, Castillo J, Kazandjian

614 A, Ortiz M. 2010. Marine biodiversity in the caribbean: Regional estimates and distribution

615 patterns. PLoS ONE 5:1-25. DOI: 10.1371/journal.pone.0011916.

616 Montes E, Muller-karger FE, Cianca A, Lomas MW, Lorenzoni L, Habtes S. 2016. Decadal

617 variability in the oxygen inventory of North Atlantic subtropical underwater captured by

618 sustained, long-term oceanographic time series observations. Global Biogeochemical Cycles

619 30:460-478. DOI: 10.1002/2015GB005183.Received.

620 Morrison JM, Nowlin WD. 1982. General distribution of water masses within the eastern

621 Caribbean Sea during the winter of 1972 and fall of 1973. Journal of Geophysical

$622 \quad$ Research: Oceans 87:4207-4229.

623 OBIS. 2019. Ocean Biogeographic Information System. Intergovernmental Oceanographic

624 Commission of UNESCO.

625 Pérez FF, Fontela M, Garcia-Ibañez MI, Mercier H, Velo A, Lherminier P, Zunino P, de la Paz

626 M, Alonso-Pérez F, Guallart EF, Padin XA. 2018. Meridional overturning circulation

627 conveys fast acidification to the deep Atlantic Ocean. Nature. 554:515-518 DOI:

$628 \quad 10.1038 /$ nature25493.

629 Quattrini AM, Demopoulos AWJ, Singer R, Roa-Varon A, Chaytor JD. 2017. Demersal fish

630 assemblages on seamounts and other rugged features in the northeastern Caribbean. Deep

631 Sea Research Part I: Oceanographic Research Papers 123:90-104. DOI:

$632 \quad$ 10.1016/j.dsr.2017.03.009.

633 Raddatz J, Titschack J, Frank N, Freiwald A, Conforti A, Osborne A, Skornitzke S, Stiller W,

634 Rüggeberg A, Voigt S, Albuquerque ALS, Vertino A, Schröder-Ritzrau A, Bahr A. 2020. 

DOI: 10.1007/s00338-019-01882-w.

637 Ragnarsson SÁ, Burgos JM, Kutti T, Beld I Van Den, Egilsdóttir H, Arnaud-haond S, Grehan A. 638 2017. The impact of Anthropogenic Activity on Cold-Water Corals. In: Rossi S ed. Marine 639 Animal Forests. Springer International Publishing, 1-35. DOI: 10.1007/978-3-319-17001-5. 640 Reed JK, Messing C, Walker BK, Brooke S, Correa TBS, Brouwer M, Udouj T, Farrington S. 641 2013. Habitat characterization, distribution, and areal extent of deep-sea coral ecosystems 642 off Florida, southeastern U.S.A. Caribbean Journal of Science 47:13-30. DOI: $643 \quad$ 10.18475/cjos.v47i1.a3.

644 Reed JK, Weaver DC, Pomponi SA. 2006. Habitat and fauna of deep-water Lophelia pertusa 645 coral reefs off the southeastern US: Blake Plateau, Straits of Florida, and Gulf of Mexico. $646 \quad$ Bulletin of Marine Science 78:343-375.

647 Reyes J, Santodomingo N, Gracia A, Borrero-Pérez G, Navas G, Mejía-Ladino LM, Bermúdez 648 A, Benavides M. 2005. Southern Caribbean azooxanthellate coral communities off 649 Colombia. In: Cold-water corals and Ecosystems. Springer, 309-330.

650 Robbins LL, Hansen ME, Kleypas JA, Meylan SC. 2010. CO2calc: A user-friendly seawater 651 carbon calculator for Windows, Mac OS X, and iOS (iPhone). US Geological Survey. 652 Roberts JM, Wheeler A, Freiwald A, Cairns SD. 2009. Cold-water corals: the biology and 653 geology of deep-sea coral habitats. Cambridge University Press, 1-334.

654 Rogers AD. 1994. The biology of seamounts. In: Advances in marine biology. Elsevier, 305655350.

656 Rogers AD. 2018. The Biology of Seamounts: 25 Years on. Advances in Marine Biology 657 79:137-224. DOI: 10.1016/BS.AMB.2018.06.001. 
658 Santodomingo N, Reyes J, Gracia A, Martínez A, Ojeda G, García C. 2007. Azooxanthellate

659 Madracis coral communities off San Bernardo and Rosario Islands (Colombian Caribbean).

660 Bulletin of Marine Science 81:273-287.

661 Schlitzer R. 2019. Ocean data view. Available at: https://odv.awi.de/

662 Schroeder WW, Brooke SD, Olson JB, Phaneuf B, McDonough JJ, Etnoyer P. 2005. Occurrence

663 of deep-water Lophelia pertusa and Madrepora oculata in the Gulf of Mexico. In: Cold-

664 water corals and ecosystems. Springer, 297-307.

665 Stefanoudis P V., Rivers M, Smith SR, Schneider CW, Wagner D, Ford H, Rogers AD, Woodall

666 LC. 2019. Low connectivity between shallow, mesophotic and rariphotic zone benthos.

667 Royal Society Open Science 6:1-13. DOI: 10.1098/rsos.190958.

668 Thresher RE, Tilbrook B, Fallon S, Wilson NC, Adkins J. 2011. Effects of chronic low carbonate 669 saturation levels on the distribution, growth and skeletal chemistry of deep-sea corals and 670 other seamount megabenthos. Marine Ecology Progress Series 442:87-99. DOI:

$671 \quad 10.3354 / \operatorname{meps} 09400$.

672 Trotter JA, Pattiaratchi C, Montagna P, Taviani M, Falter J, Thresher R, Hosie A, Haig D,

673 Foglini F, Hua Q. 2019. First ROV exploration of the Perth Canyon: Canyon setting, faunal 674 observations, and anthropogenic impacts. Frontiers in Marine Science 6:1-24.

675 Venn A, Tambutté E, Holcomb M, Allemand D, Tambutté S. 2011. Live tissue imaging shows 676 reef corals elevate $\mathrm{pH}$ under their calcifying tissue relative to seawater. PLoS ONE 6:1-9.

677 DOI: 10.1371/journal.pone.0020013.

678 Wagner D, Sowers D, Williams SM, Auscavitch S, Blaney D, Cromwell M. 2019. Océano

679 Profundo 2018: Exploring deep sea habitats off Puerto Rico and the US Virgin Islands. 
680 Office of Ocean Exploration and Research, NOAA, Silver Spring, MD 20910, OER

681 Expedition Report EX-18-11, 1-171. DOI: 10.25923/wc2n-qg29

682 Watling L, Norse EA. 1998. Disturbance of the Seabed by Mobile Fishing Gear: A Comparison 683 to Forest Clearcutting. Conservation Biology 12:1180-1197.

684

685

686 
Figure 1

Multibeam bathymetric map of the Anegada Passage seamounts.

The locations of Dog, Conrad, and Noroît Seamount are indicated in bold. Dive locations are overlaid in yellow and labeled by dive number. The bathymetry color ramp in the lower right indicates depth values measured in meters. Transect segments lengths are not drawn to scale.

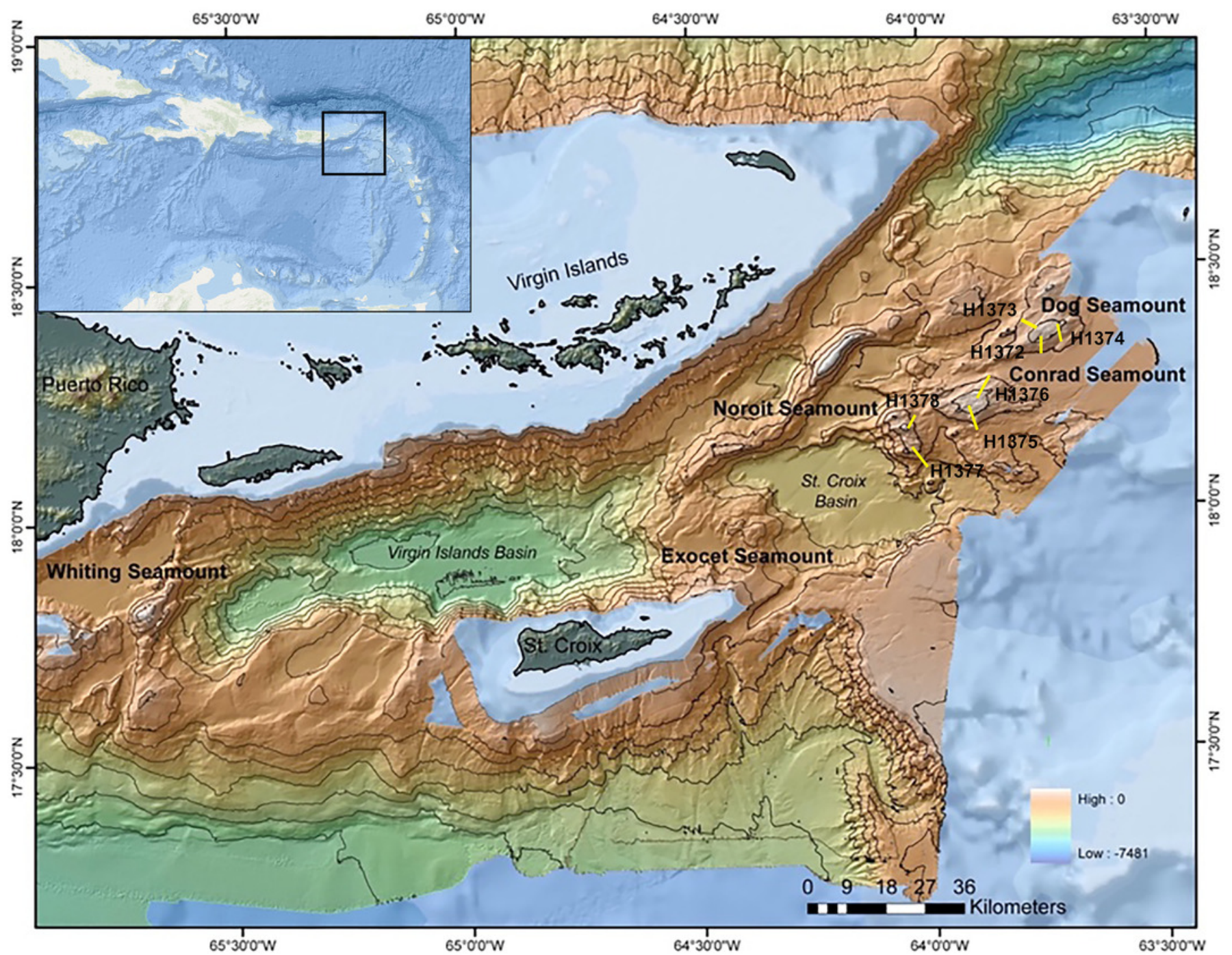


Figure 2

Temperature-Salinity plot for the Anegada Passage based on CTD water column profiles.

Water masses are overlaid and abbreviated by the following: SUW=Subtropical underwater, SSW=Sargasso Sea Water, TACW= Tropical Atlantic Central Water, AAIW=Antarctic Intermediate Water, and NADW=North Atlantic Deep Water. Isopycnal surfaces $\left(\sigma_{\theta}\right)$ are indicated in gray. 


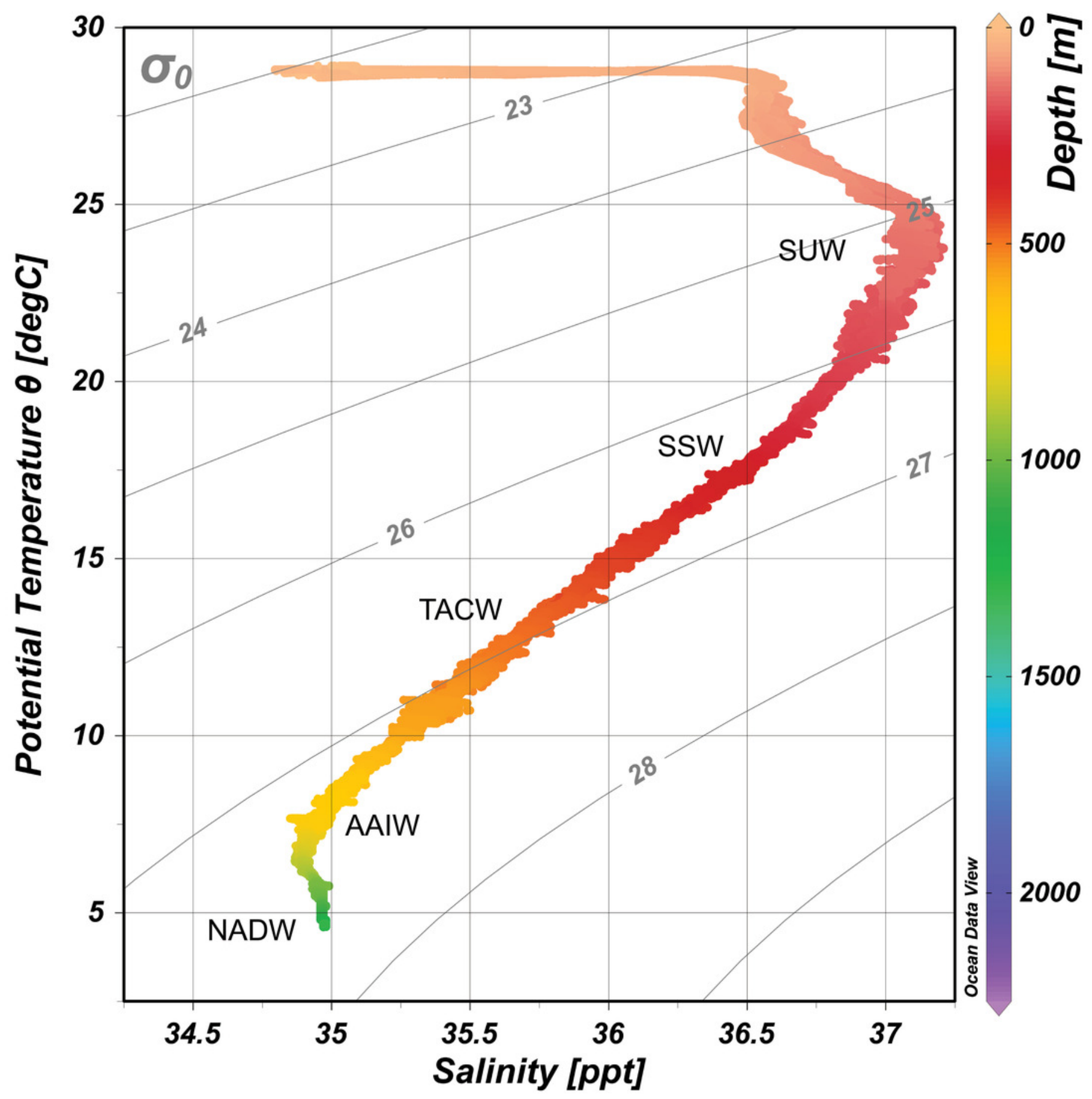


Figure 3

Depth distribution for scleractinian and stylasterid corals occurring on Dog, Conrad, and Noroît Seamounts.

Box plots represent the interquartile range with whiskers extending from the upper and lower quartiles to the minimum and maximum values. Horizontal lines represent the median depth. Individual points represent outliers. Species are arranged on the $x$-axis from shallowest to deepest by median depth of occurrence.

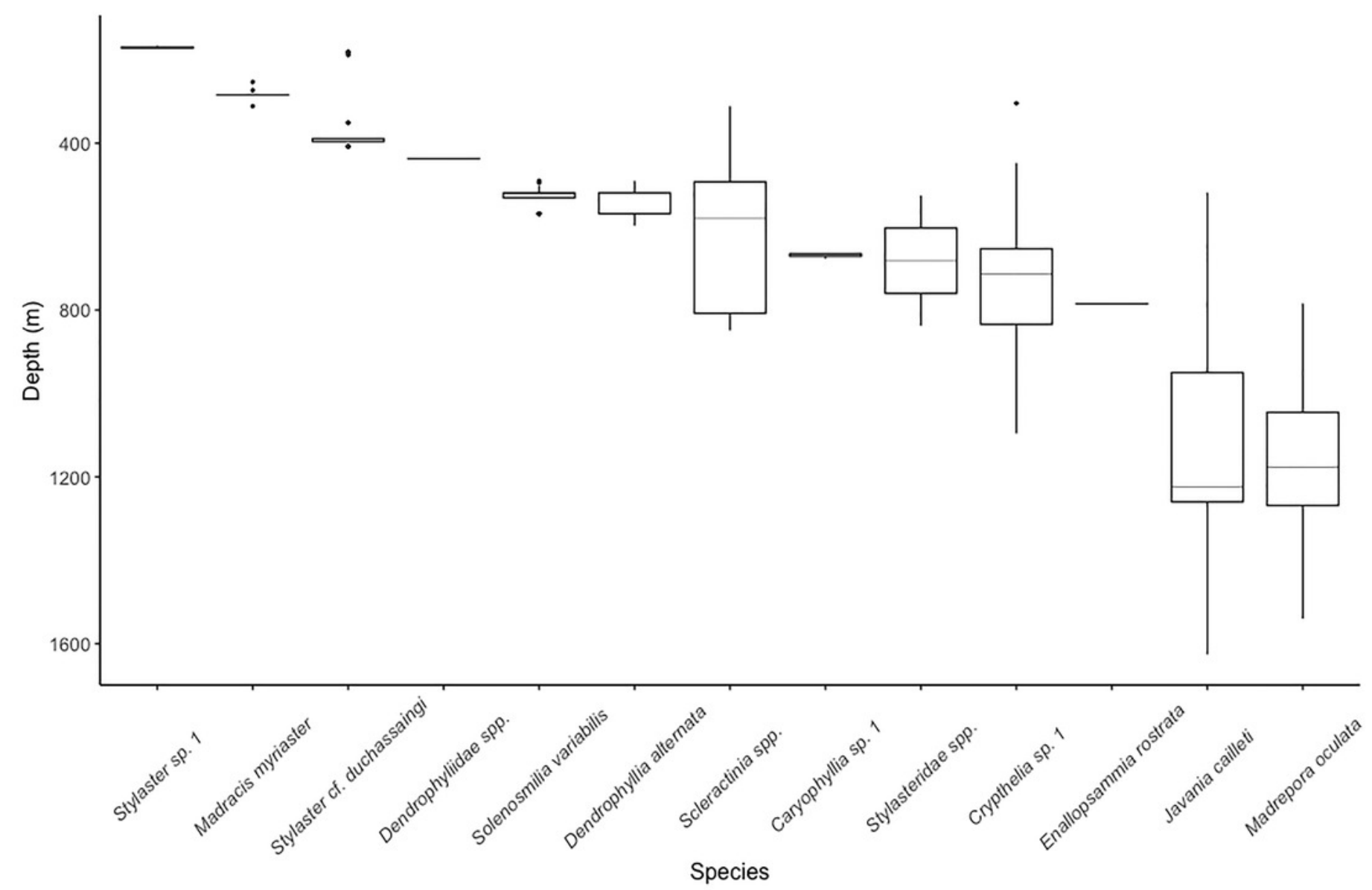




\section{Figure 4}

Distribution of scleractinian and stylasterid species against model predicted $\Omega_{\text {Arag }}$ values on the Anegada Passage seamounts.

Box plots represent the interquartile range with whiskers extending from the upper and lower quartiles to the minimum and maximum values. Vertical lines represent the median aragonite saturation state. Individual points represent outliers. Species are arranged on the $y$-axis from highest to lowest median aragonite saturation occurrence. A solid red vertical line indicates the aragonite saturation horizon, where $\Omega_{\text {Arag }}=1$. 


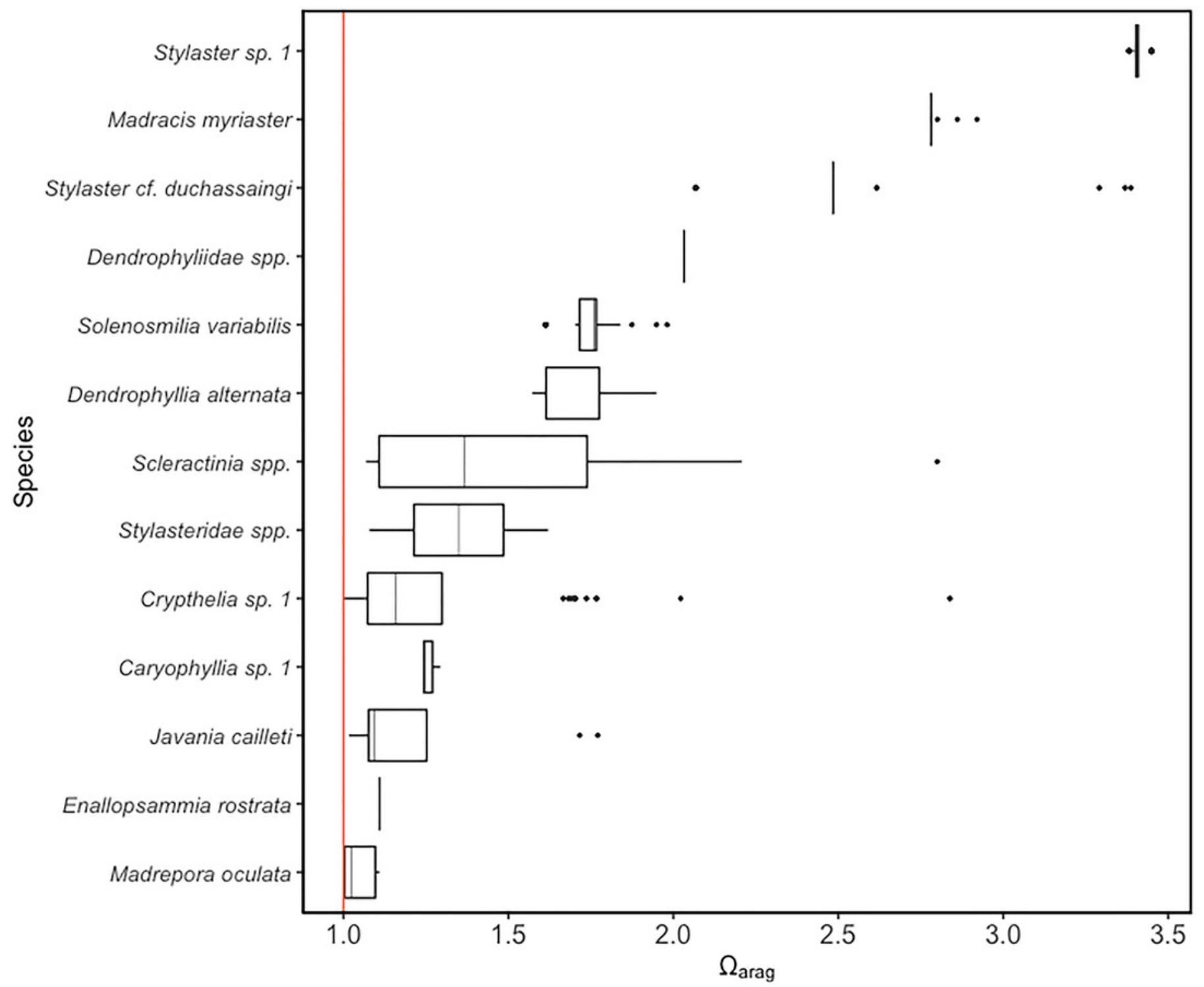


Figure 5

Species accumulation curves for the Anegada Passage seamounts.

Curves are plotted for all transects on Dog Seamount (276-1035 m), Conrad Seamount (162-1267 m), Noroit Seamount (881-2157 m), as well as for all three seamounts combined (162-2157 m).

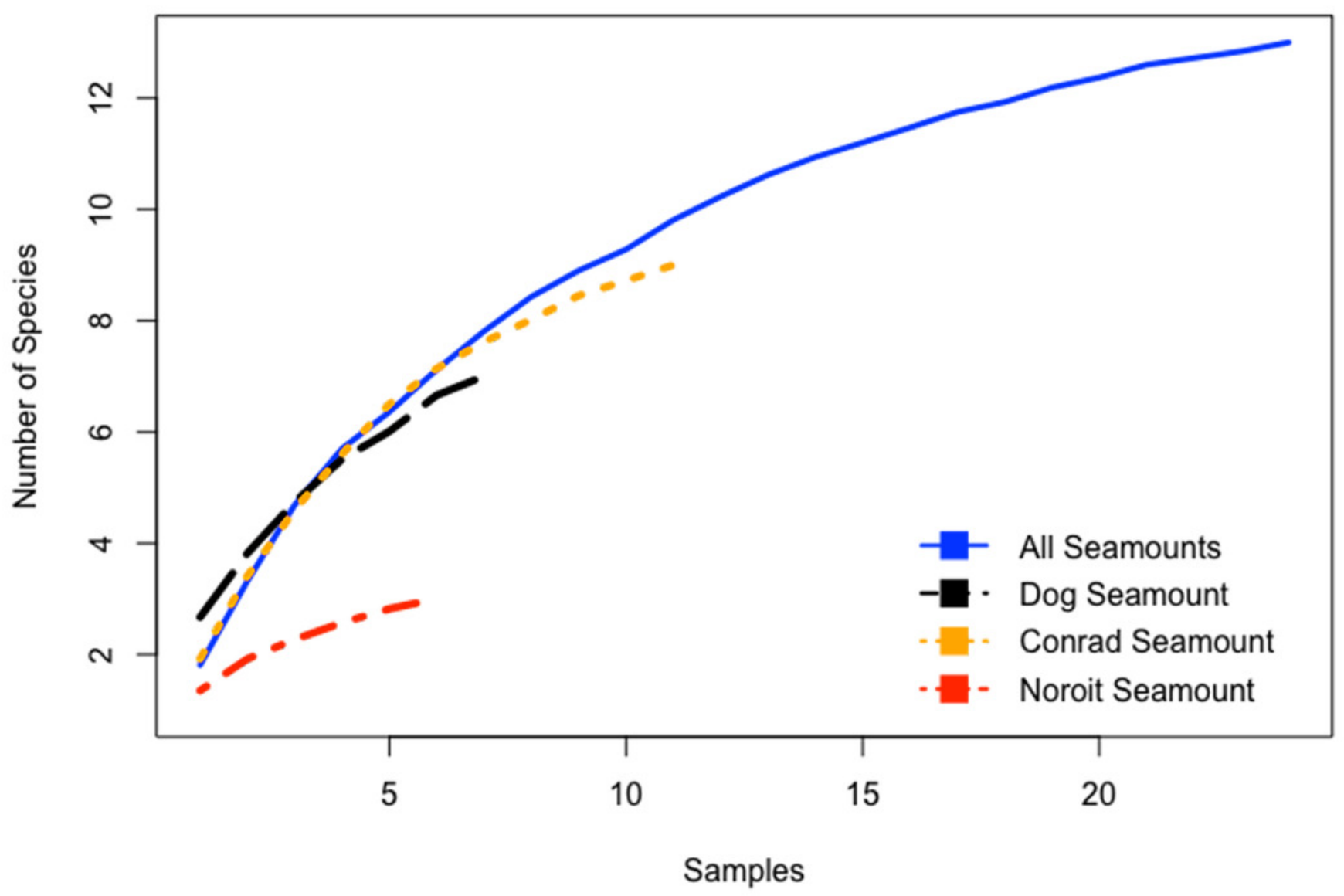


Figure 6

Non-metric multidimensional scaling analysis of standardized, fourth-root transformed coral assemblages on Dog, Conrad, and Noroît Seamounts.

SIMPROF groups are overlaid around significant groupings at the $95 \%$ level or above. Depth ranges displayed within each statistical grouping are indicated in black text. Water masses in the legend are abbreviated by the following: Subtropical underwater (SUW), Sargasso Sea Water (SSW), Tropical Atlantic Central Water (TACW), Antarctic Intermediate Water (AAIW), and North Atlantic Deep Water (NADW).

Resemblance: 517 Bray-Curtis similgrity

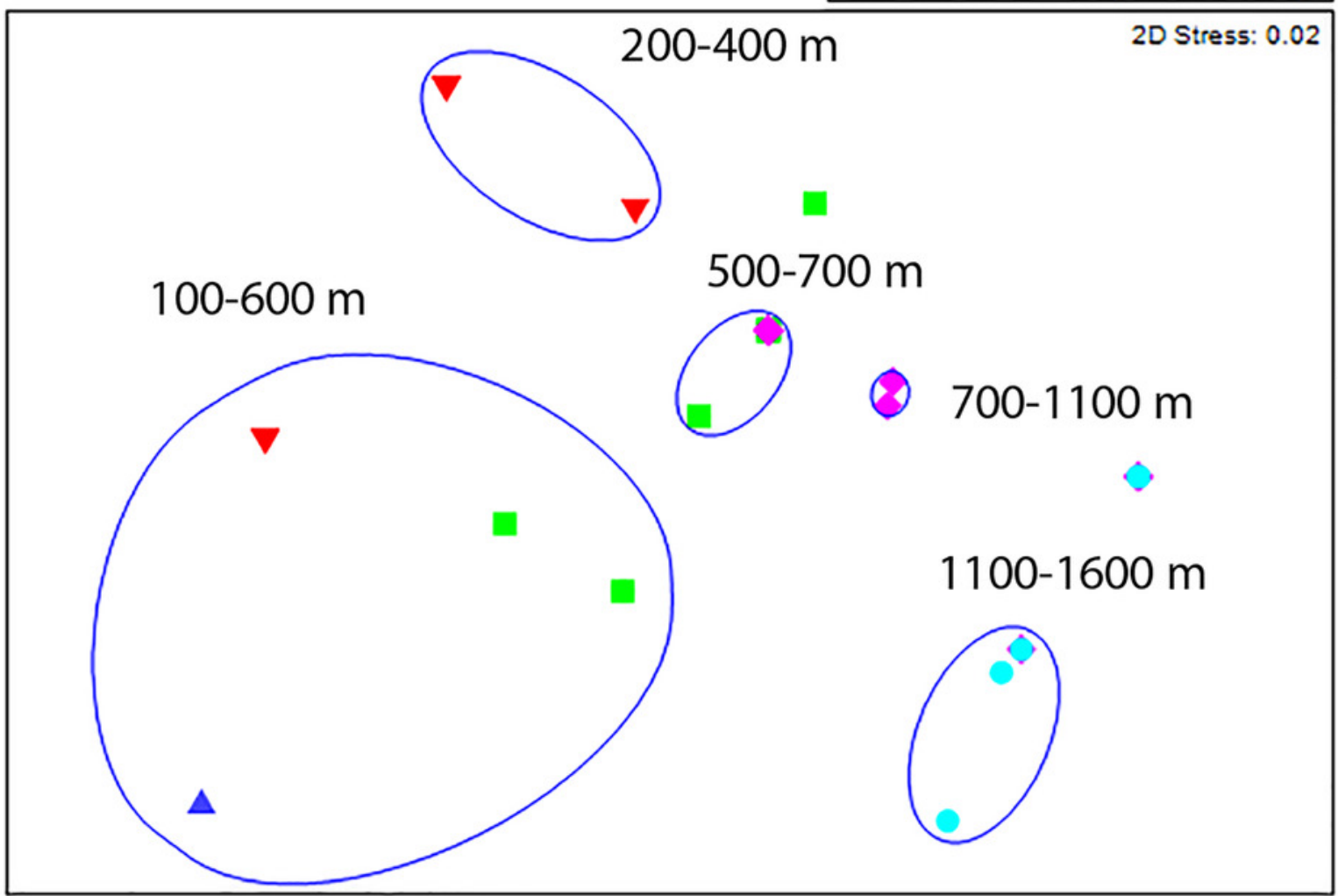

\begin{tabular}{|l|}
\hline SIMPROF \\
\hline Water Mass \\
$\Delta$ SUW \\
$\nabla$ SSW \\
TACW \\
AAIW \\
NADW \\
\hline
\end{tabular}




\section{Figure 7}

Distance-based linear model and redundancy analysis of coral assemblages and oceanographic variables.

Sample points represent one $100 \mathrm{~m}$ depth assemblage. Axes shown are the results of a distance-based redundancy analysis with percent variation explained by the first and second axes. Water masses in the legend are abbreviated by the following: Subtropical underwater (SUW), Sargasso Sea Water (SSW), Tropical Atlantic Central Water (TACW), Antarctic Intermediate Water (AAIW), and North Atlantic Deep Water (NADW).

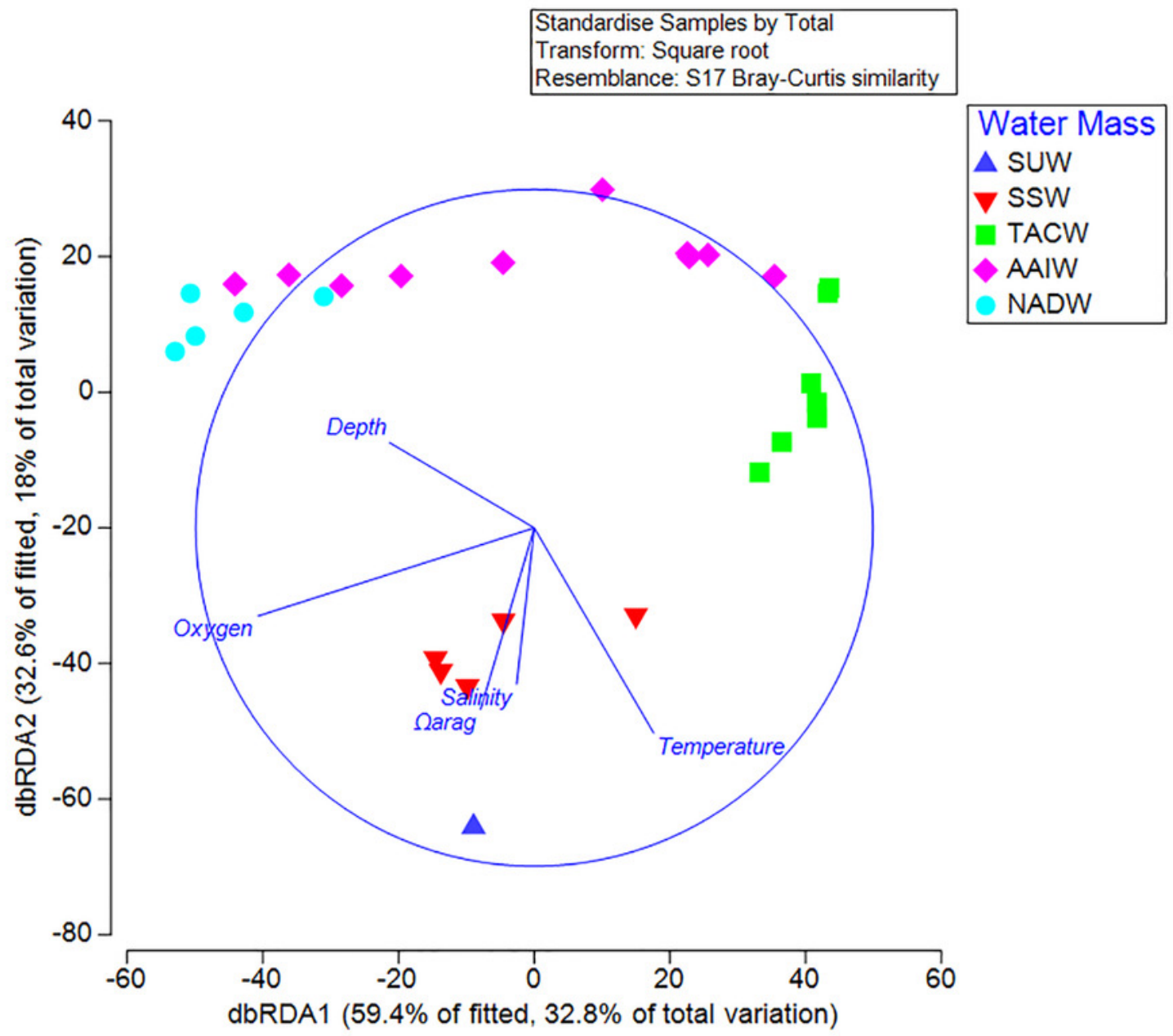


Figure 8

Deep-water scleractinians from the Anegada Passage seamounts.

(A) Enallopsammia rostrata. (B) Madrepora oculata. (C) Madracis myriaster. (D) Dendrophyllia alternata. (E) Javania cailleti. (F) Solenosmilia variabilis. 


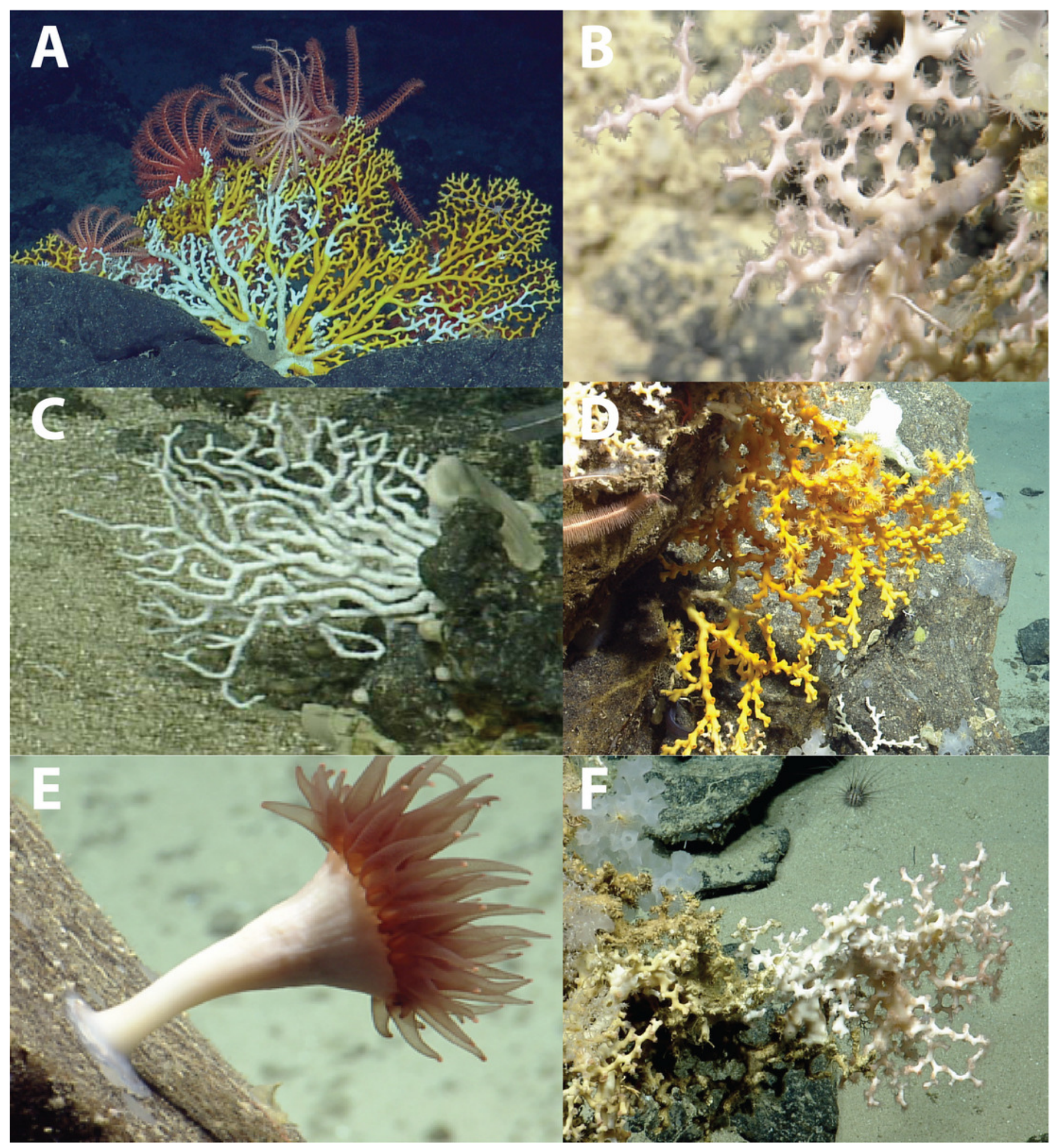


Figure 9

Deep-water stylasterids from the Anegada Passage seamounts.

(A) Crypthelia sp. 1. (B) Stylaster cf. duchassaingi. (C) Stylaster sp. 1. 

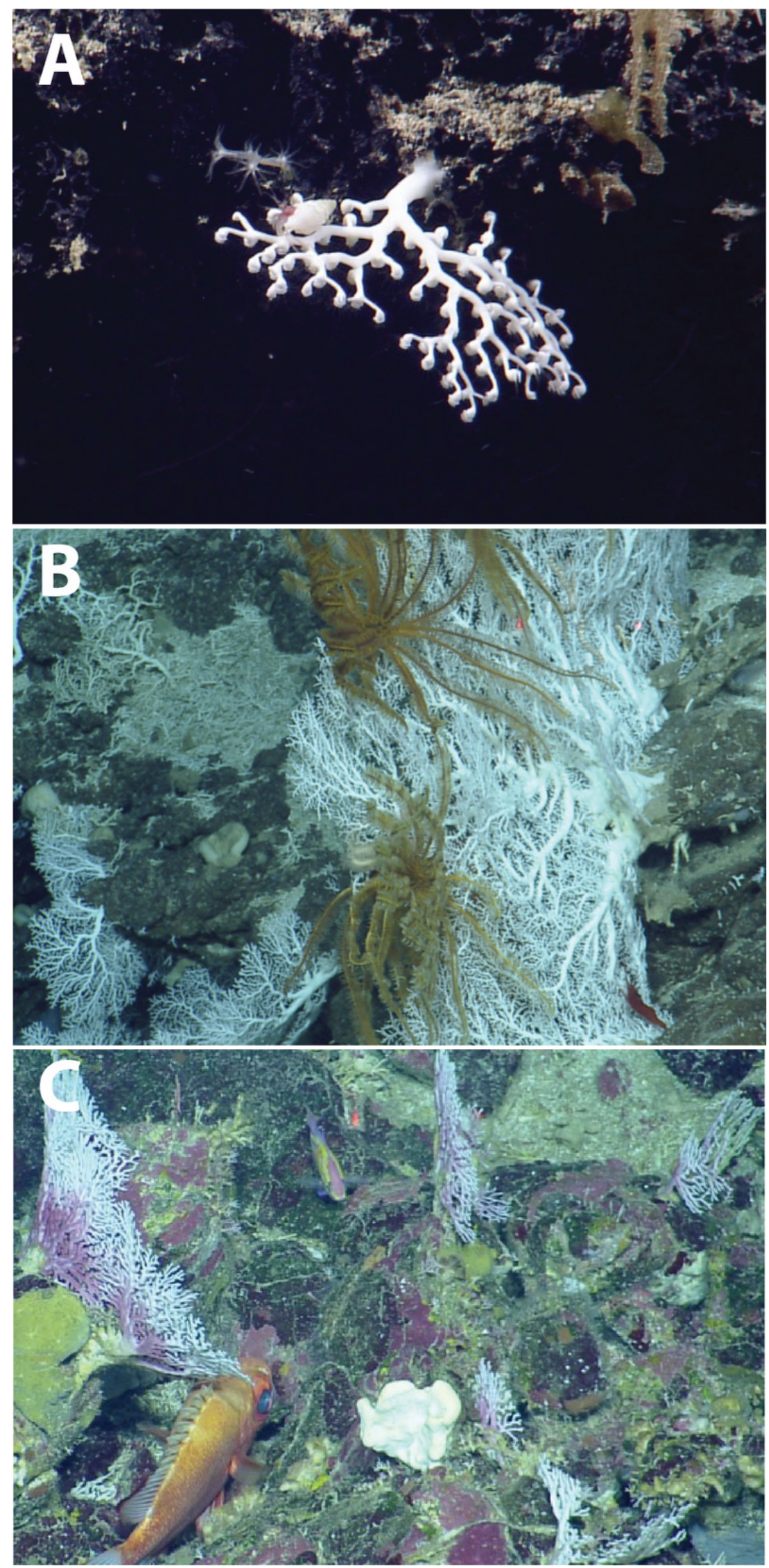

Peer) reviewing PDF | (2018:04:27834:2:0:NEW 11 Jun 2020) 


\section{Table 1 (on next page)}

ROV dive transect details for 2014 surveys of the Anegada Passage seamounts.

Start and end coordinates for each transect, time spent in visual contact with the seafloor, and number of water samples collected at depth over the dive interval are indicated. 
1 Table 1: ROV dive transect details for 2014 surveys of the Anegada Passage seamounts. Start

2 and end coordinates for each transect, time spent in visual contact with the seafloor, and number

3 of water samples collected at depth over the dive interval are indicated.

\begin{tabular}{|c|c|c|c|c|c|c|}
\hline Dive & $\begin{array}{l}\text { Seam } \\
\text { ount }\end{array}$ & $\begin{array}{l}\text { Start } \\
\text { Coordinates }\end{array}$ & $\begin{array}{l}\text { End } \\
\text { Coordinates }\end{array}$ & $\begin{array}{l}\text { Depth } \\
\text { Range (m) }\end{array}$ & $\begin{array}{l}\text { Number of } \\
\text { Niskin } \\
\text { Bottle } \\
\text { Samples } \\
\end{array}$ & $\begin{array}{l}\text { Total Bottom } \\
\text { Time (hh:mm) }\end{array}$ \\
\hline $\begin{array}{l}\mathrm{H} 137 \\
2\end{array}$ & Dog & $\begin{array}{l}18^{\circ} 18.7385 \mathrm{~N} \\
63^{\circ} 46.0896 \\
W\end{array}$ & $\begin{array}{l}18^{\circ} 19.6177 \\
N \\
63^{\circ} 46.1645 \\
W\end{array}$ & $717-1035$ & 6 & 07:56 \\
\hline $\begin{array}{l}\mathrm{H} 137 \\
3\end{array}$ & Dog & $\begin{array}{l}18^{\circ} 22.6480 \mathrm{~N} \\
63^{\circ} 46.1953 \\
\mathrm{~W}\end{array}$ & $\begin{array}{l}18^{\circ} 21.9711 \\
N \\
63^{\circ} 45.9306 \\
W\end{array}$ & $503-784$ & 6 & 11:09 \\
\hline $\begin{array}{l}\mathrm{H} 137 \\
4\end{array}$ & Dog & $\begin{array}{l}18^{\circ} 20.4464 \mathrm{~N} \\
63^{\circ} 43.6091 \\
W\end{array}$ & $\begin{array}{l}18^{\circ} 21.9311 \\
N \\
63^{\circ} 43.5024 \\
W\end{array}$ & $276-601$ & 5 & 09:58 \\
\hline $\begin{array}{l}\mathrm{H} 137 \\
5\end{array}$ & $\begin{array}{l}\text { Conra } \\
\text { d }\end{array}$ & $\begin{array}{l}18^{\circ} 10.5420 \mathrm{~N} \\
63^{\circ} 53.1020 \\
W\end{array}$ & $\begin{array}{l}18^{\circ} 13.0029 \\
N \\
63^{\circ} 53.3459 \\
W\end{array}$ & $162-876$ & 5 & $31: 40$ \\
\hline $\begin{array}{l}\mathrm{H} 137 \\
6\end{array}$ & $\begin{array}{l}\text { Conra } \\
\text { d }\end{array}$ & $\begin{array}{l}18^{\circ} 16.4904 \mathrm{~N} \\
63^{\circ} 52.3364 \\
W\end{array}$ & $\begin{array}{l}18^{\circ} 14.2223 \\
N \\
63^{\circ} 52.9767 \\
W\end{array}$ & $344-1267$ & 6 & $22: 38$ \\
\hline $\begin{array}{l}\mathrm{H} 137 \\
7\end{array}$ & Noroît & $\begin{array}{l}18^{\circ} 05.4657 \\
N \\
64^{\circ} 00.1741 \\
W\end{array}$ & $\begin{array}{l}18^{\circ} 07.0695 \\
N \\
64^{\circ} 01.1760 \\
W\end{array}$ & $881-2157$ & 6 & $17: 10$ \\
\hline $\begin{array}{l}\mathrm{H} 137 \\
8\end{array}$ & Noroît & $\begin{array}{l}18^{\circ} 09.6969 \\
N \\
64^{\circ} 01.3606 \\
W\end{array}$ & $\begin{array}{l}18^{\circ} 09.4122 \\
N \\
64^{\circ} 01.8888 \\
W\end{array}$ & $949-1035$ & 2 & 06:01 \\
\hline
\end{tabular}

4 


\section{Table 2 (on next page)}

Summary of records and environmental variables for each taxon.

Ranges of values for number of observations, depth, temperature, salinity, dissolved oxygen, model predicted $\Omega_{\text {Arag }}$, and colony height are reported for each species by taxonomic grouping. 
1 Table 2: Summary of records and environmental variables for each taxon. Ranges of values for number of observations, depth,

2 temperature, salinity, dissolved oxygen, model predicted $\Omega_{\text {Arag }}$, and colony height are reported for each species by taxonomic

3 grouping.

\begin{tabular}{|c|c|c|c|c|c|c|c|c|c|}
\hline Class & Family & Species & $\begin{array}{c}\text { Number of } \\
\text { observations }\end{array}$ & Depth (m) & $\begin{array}{c}\text { Temperature } \\
\left({ }^{\circ} \mathrm{C}\right)\end{array}$ & Salinity (psu) & $\begin{array}{c}\text { Dissolved } \\
\text { oxygen } \\
(\mathrm{mg} / \mathrm{L})\end{array}$ & $\begin{array}{c}\text { Model } \\
\text { Predicted } \\
\Omega_{\text {arag }} \\
\end{array}$ & Height $(\mathrm{cm})$ \\
\hline \multirow{4}{*}{ Hydrozoa } & \multirow{4}{*}{ Stylasteridae } & Stylaster sp. 1 & 65 & $166-174$ & $22.1-22.5$ & $37.00-37.05$ & 7-7.12 & 3.38-3.45 & - \\
\hline & & Crypthelia sp. 1 & 49 & $304-1096$ & $4.9-18.0$ & $34.53-36.55$ & $2.41-7.22$ & $0.99-2.83$ & $1-12$ \\
\hline & & $\begin{array}{c}\text { Stylaster cf. } \\
\text { duchassaingi }\end{array}$ & 30 & $181-408$ & $13.8-22.1$ & $35.82-37.01$ & $5.39-6.99$ & 2.07-3.39 & $12-37$ \\
\hline & & Stylasteridae spp. & 2 & $525-838$ & $6.7-10.9$ & $34.89-35.39$ & $4.96-5.28$ & $1.08-1.62$ & $3-5$ \\
\hline \multirow{9}{*}{ Anthozoa } & \multirow[t]{2}{*}{ Caryophylliidae } & $\begin{array}{c}\text { Solenosmilia } \\
\text { variabilis }\end{array}$ & 44 & $490-569$ & $10.9-13.3$ & $35.37-35.75$ & $4.88-5.15$ & $1.61-1.98$ & $12-18$ \\
\hline & & Caryophyllia sp. 1 & 3 & $665-677$ & $8.2-8.7$ & $35.03-35.07$ & $4.78-4.86$ & $1.24-1.29$ & - \\
\hline & Oculinidae & $\begin{array}{c}\text { Madrepora } \\
\text { oculata }\end{array}$ & 22 & $784-1540$ & 4.3-6.9 & $34.53-34.97$ & $5.22-8.23$ & $1.00-1.10$ & $10-125$ \\
\hline & Pocilloporidae & $\begin{array}{l}\text { Madracis } \\
\text { myriaster }\end{array}$ & 22 & $253-311$ & $17.6-18.7$ & $36.49-36.65$ & $6.83-7.01$ & $2.78-2.92$ & $6-35$ \\
\hline & Incertae familiae & $\begin{array}{c}\text { Scleractinia spp. } \\
\text { (solitary) }\end{array}$ & 11 & $311-849$ & $6.5-17.8$ & $34.83-36.51$ & $4.76-6.98$ & $1.07-2.8$ & $4-5$ \\
\hline & \multirow{3}{*}{ Dendrophylliidae } & $\begin{array}{c}\text { Dendrophyllia } \\
\text { alternata }\end{array}$ & 5 & $490-598$ & $10.7-13$ & $35.33-35.71$ & $4.84-5.13$ & $1.57-1.95$ & 16 \\
\hline & & $\begin{array}{c}\text { Enallopsammia } \\
\text { rostrata }\end{array}$ & 2 & 785 & 7.0 & 34.921 & 5.2 & 1.11 & $20-75$ \\
\hline & & $\begin{array}{c}\text { Dendrophylliidae } \\
\text { spp. }\end{array}$ & 1 & 437 & 13.6 & 35.794 & 5.29 & 2.03 & 5 \\
\hline & Flabellidae & Javania cailleti & 8 & $518-1626$ & $4.2-12.0$ & $34.557-35.54$ & $4.96-8.34$ & $1.02-1.77$ & $4-7$ \\
\hline
\end{tabular}

4 


\section{Table 3(on next page)}

Summary of measured values of $\Omega_{\text {Arag }}$ from water samples taken directly adjacent to corals.

Sampling events are reported for each species arranged by taxonomic grouping. 
1 Table 3: Summary of measured values of $\Omega_{\text {Arag }}$ from water samples taken directly adjacent to

2 corals. Sampling events are reported for each species arranged by taxonomic grouping.

\begin{tabular}{|c|c|c|c|c|}
\hline Class & Family & Species & $\begin{array}{c}\text { Number of } \\
\text { adjacent } \\
\text { water } \\
\text { samples }\end{array}$ & $\begin{array}{c}\boldsymbol{\Omega}_{\text {arag }} \\
\text { measured }\end{array}$ \\
\hline \multirow{4}{*}{ Hydrozoa } & \multirow{4}{*}{ Stylasteridae } & Stylaster sp. 1 & 0 & - \\
\hline & & Crypthelia sp. 1 & 0 & - \\
\hline & & $\begin{array}{l}\text { Stylaster cf. } \\
\text { duchassaingi }\end{array}$ & 0 & - \\
\hline & & Stylasteridae spp. & 0 & - \\
\hline \multirow{9}{*}{ Anthozoa } & \multirow{2}{*}{ Caryophylliidae } & Solenosmilia variabilis & 1 & 1.63 \\
\hline & & Caryophyllia sp. 1 & 1 & 1.24 \\
\hline & Oculinidae & Madrepora oculata & 2 & $1.13-1.16$ \\
\hline & Pocilloporidae & Madracis myriaster & 1 & 2.7 \\
\hline & Incertae familiae & $\begin{array}{c}\text { Scleractinia spp. } \\
\text { (solitary) }\end{array}$ & 0 & - \\
\hline & \multirow{3}{*}{ Dendrophylliidae } & Dendrophyllia alternata & 1 & 1.35 \\
\hline & & Enallopsammia rostrata & 1 & 1.21 \\
\hline & & Dendrophylliidae spp. & 1 & 1.82 \\
\hline & Flabellidae & Javania cailleti & 1 & 1.16 \\
\hline
\end{tabular}

3 